\title{
Farnesyl phenolic enantiomers as natural MTH1 inhibitors from Ganoderma sinense
}

\author{
Ya Gao ${ }^{2, *}$, Lihan Zhu ${ }^{1, *}$, Jing Guo ${ }^{2}$, Ting Yuan ${ }^{1}$, Liqing Wang ${ }^{1}$, Hua Li, ${ }^{1,2}$ and Lixia \\ Chen ${ }^{1}$ \\ ${ }^{1}$ Wuya College of Innovation, School of Traditional Chinese Materia Medica, Key Laboratory of Structure-Based Drug Design \\ \& Discovery, Ministry of Education, Shenyang Pharmaceutical University, Shenyang 110016, People's Republic of China \\ ${ }^{2}$ Hubei Key Laboratory of Natural Medicinal Chemistry and Resource Evaluation, School of Pharmacy, Tongji Medical College, \\ Huazhong University of Science and Technology, Wuhan 430030, People's Republic of China \\ *These authors have contributed equally to this work \\ Correspondence to: Hua Li, email: li_hua@hust.edu.cn \\ Lixia Chen, email: syzyclx@163.com
}

Keywords: MTH1; natural inhibitors; farnesyl phenolic compounds; anti-tumor; Ganoderma sinense

Received: May 09, $2017 \quad$ Accepted: August 17, $2017 \quad$ Published: September 30, 2017

Copyright: Gao et al. This is an open-access article distributed under the terms of the Creative Commons Attribution License 3.0 (CC BY 3.0), which permits unrestricted use, distribution, and reproduction in any medium, provided the original author and source are credited.

\section{ABSTRACT}

Cancer cells are more addictive to MTH1 than normal cells because of their dysfunctional redox regulations. MTH1 plays an important role to maintain tumor cell survival, while it is not indispensable for the growth of normal cells. Farnesyl phenols having a coumaroyl substitution are rather uncommon in nature. Eight farnesyl phenolic compounds with such substituent moiety (1-8), including six new ones, ganosinensols E-J (1-6) were isolated from the 95\% EtOH extract of the fruiting bodies of Ganoderma sinense. Four pairs of enantiomers 1/2, 3/4, 5/6 and 7/8 were resolved by HPLC using a Daicel Chiralpak IE column. Their structures were elucidated from extensive spectroscopic analyses and comparison with literature data. The absolute configurations of C-1' in 1-6 were assigned by ECD spectra. These compounds were predicted to have high binding affinity to MTH1 through virtual ligand screening. The enzyme inhibition experiments and cell-based assays confirmed their inhibitory effects on MTH1. Furthermore, siRNA knockdown experiments and the cellular thermal shift assay (CETSA) confirmed that the farnesyl phenolic enantiomers specifically bound with MTH1 in intact cells. Meanwhile, the low cytotoxicity of 1-8 on normal human cells further verified their good selectivity and specificity to MTH1. These active structures are expected to be potential anti-cancer lead compounds.

\section{INTRODUCTION}

A reason for increase risks of cancer, including its aetiology, progression and metastasis, is an imbalance between the production of reactive oxygen species (ROS) and cellular anti-oxidative defenses [1]. Meanwhile, an increase ROS tension can cause damage to mitochondrial deoxynucleoside triphosphate (dNTP) pool, and it results in DNA damage [2,3]. MTH1, a homologue of bacterial mutT, is a nucleotide pool sanitizing enzyme which converts those oxidative nucleotides such as 8-oxo-dGTP or 2-OH-dATP into their corresponding monophosphates 8-oxod-GMP or 2-OH-dAMP, respectively $[2,4]$. This hydrolysis reaction ensures that these oxidized nucleotides are unable to be recognized by DNA polymerase, thus avoiding them to be incorporated into DNA, and finally preventing the mispairing of bases during replication and transversion mutations $[5,6]$. It is reported that MTH1 plays an important role to maintain tumor cell survival, [7] on the contrary, normal cells do not need MTH1 [2]. Therefore, MTH1 may be only associated with tumor cell growth, which represents a new attractive 
therapeutic targets for the treatment of cancers these days [8]. Although there are a few chemically synthesized small molecule MTH1 inhibitors available in recent years, such as TH287/TH588, (S)-crizotinib, SCH51344, organometallic complexes and 8-halogenated 7-deaza-2'deoxyguanosine triphosphates $[2,8,9,10]$. Nevertheless, there are no any natural MTH1 inhibitors so far and the MTH1 inhibitors mentioned above are far more from clinical use. Natural products have been acknowledged as an important source for anticancer drug discovery and development [11]. Our group is making efforts to find effective MTH1 inhibitors from natural products by virtual ligand screening techniques. About 500 compounds from a small in-house database of natural products were screened against the MTH1 model in silico based on its X-ray structure (PDB code: 4C9X) [8] by ICM-Pro 3.8.1 molecular docking software (Molsoft, LLC) [12].

Ganoderma sinense (Chinese name: Lingzhi) has been used as a folk medicine for thousands of years in China and is a well-known traditional Chinese medicine. The fungal family Ganoderma contains more than 100 species, with wide distribution in China. Ganoderma sinense, together with Ganoderma lucidum, are recorded in Chinese pharmacopoeia for the treatment of asthma and hypertension [13]. Recent studies showed that mushrooms of Ganoderma possess antitumor, [14-16] anti-inflammatory, $[17,18]$ immune regulation, $[19,20]$ hepatoprotective [21] and other pharmacological effects. Previous phytochemical investigations have resulted in the isolation of more than 300 compounds from Ganoderma, [22-25] including polysaccharides, triterpenes, sterols, and a few farnesyl phenolic substances [26-30].

A chemical investigation on the edible fruiting bodies of $G$. sinense led to the isolation of eight farnesyl phenolic compounds (1-8) (Figure 1a) (the chromatography graphs and spectra see Supplementary Figures 1-33), including six new ones, ganosinensols E-J (1-6), and two known ones, ganosinensols C-D (7-8) [31]. All of these farnesyl phenols possess a coumaroyl substitution in their structures, which are rather unusual in nature. They were predicted to have the high binding affinity to MTH1 with more negative $\mathrm{mfScores}$ among all the compounds from the in-house database. The enzyme inhibition experiments and cellbased assays confirmed their inhibitory effects on MTH1. The cytotoxicities of 1-8 in normal human cells were also evaluated. The siRNA knockdown experiments and the CETSA were carried out to verify the interaction between compounds and MTH1 protein in intact cells.

\section{RESULTS}

\section{Isolation and structure elucidation}

Compounds 1 and 2 was assigned the molecular formula as $\mathrm{C}_{31} \mathrm{H}_{36} \mathrm{O}_{9}$ based on ${ }^{13} \mathrm{C}$ NMR data and the $[\mathrm{M}+$ $\mathrm{Na}]^{+}$at $m / z 575.2260$ (calcd 575.2257) ion in the positive
HRESIMS. The ${ }^{1} \mathrm{H},{ }^{13} \mathrm{C}$ NMR (Table 1) and HSQC spectra suggested the presence of a 1,3,5-trisubstituted dihydroxybenzene moiety $\left[\delta_{H} 6.94(1 \mathrm{H}\right.$, br s), $6.67(2 \mathrm{H}$, br s)], a $p$-substituted hydroxybenzene structure $\left[\delta_{H} 7.45\right.$ $(2 \mathrm{H}, \mathrm{d}, J=8.4 \mathrm{~Hz}), 6.80(2 \mathrm{H}, \mathrm{d}, J=8.4 \mathrm{~Hz})]$, one methyl group, seven methylene groups, one oxygenated tertiary carbon, and two ester carbonyls. The ${ }^{1} \mathrm{H}$ and ${ }^{13} \mathrm{C}$ NMR data (Table 1) were consistent with those of 7 and 8, [31] except that the $\Delta^{6,7}$ double bond $\left(\delta_{C} 140.9 / 127.5\right.$ and $\delta_{H}$ 5.24) was reduced $\left(\delta_{C} 41.0 / 31.5\right.$ and $\left.\delta_{H} 1.47 / 1.31\right)$ in 1 and 2. C-5'-C-6', C-7'-C-8' and C-7'-C-15' moieties were identified by the ${ }^{1} \mathrm{H}-{ }^{1} \mathrm{H}$ COSY spectrum. The HMBC correlations (Figure 1b) from H-6' $\left(\delta_{H} 1.31\right)$ to $\mathrm{C}-5^{\prime} / \mathrm{C}-$ $7^{\prime} / \mathrm{C}-8^{\prime}$, and $\mathrm{H}-7^{\prime}\left(\delta_{H} 1.47\right)$ to $\mathrm{C}-6^{\prime} / \mathrm{C}-8^{\prime} / \mathrm{C}-15^{\prime}$, corroborated the hydration of $\Delta^{6,7}$ double bond. The $E$ configuration of $\Delta^{10^{\prime}, 11^{\prime}}$ double bond was assigned according to the NOESY correlation of $\mathrm{H}-10^{\prime}$ with $\mathrm{H}-12^{\prime}$.

The ECD and optical rotation data $\left([\alpha]_{\mathrm{D}}^{20}-5\right)$, as well as the completely identical NMR spectroscopic data indicated that the mix of 1 and 2 was an enantiomeric mixture. Subsequent chiral resolution on Chiralpak IE liquid chromatography afforded the enantiomers 1 and 2 in a ratio of approximately 1:1 (Figure 2). In the ECD spectrum, negative and positive Cotton effects at 210 and $230 \mathrm{~nm}$ suggested that the absolute configuration of $\mathrm{C}-1$ ' of 1 should be $R$, correspondingly, 2 was 1 'S. On the basis of these findings, the structures of compounds 1 and 2 were defined as $(5 R)-3-\{9-[(E)$ coumaroyl]-4-hydroxymethyl-8-methyl-7-nonene $\}-5$ (3,5-dihydroxyphenyl)-5-methoxy-2(5H)-furanone and (5S)-3-\{9-[(E)-coumaroyl]-4-hydroxymethyl -8-methyl7-nonene $\}$-5-(3,5-dihydroxyphenyl)-5-methoxy-2(5H)furanone, and they were named ganosinensol $\mathrm{E}$ and ganosinensol $\mathrm{F}$, respectively.

Compounds 3 and 4 were determined to have a molecular formula of $\mathrm{C}_{30} \mathrm{H}_{34} \mathrm{O}_{8}$, as deduced from ${ }^{13} \mathrm{C}$ NMR spectroscopic and HRESIMS data $[\mathrm{M}+\mathrm{Na}]^{+}$at $\mathrm{m} / \mathrm{z} 545.2153$ (calcd 545.2151), implying 14 indices of hydrogen deficiency, and 2 mass units higher than the known compounds, ganosinensols $\mathrm{A}$ and $\mathrm{B}$ [31]. The ${ }^{1} \mathrm{H}$ and ${ }^{13} \mathrm{C}$ NMR data (Table 1) indicated that the $\Delta^{6,7}$ double bond $\left(\delta_{C} 139.9 / 124.6\right.$ and $\left.\delta_{H} 5.18\right)$ in ganosinensols $\mathrm{A}$ and B was saturated $\left(\delta_{C} 41.1 / 31.6\right.$ and $\left.\delta_{H} 1.50 / 1.43\right)$ in 3 and 4 , which was further determined by the $\mathrm{HMBC}$ correlations (Figure $1 \mathrm{~b})$ from $\mathrm{H}-6^{\prime}\left(\delta_{H} 1.43\right)$ to $\mathrm{C}-5^{\prime} / \mathrm{C}-7^{\prime} / \mathrm{C}-15^{\prime}$, and $\mathrm{H}-7^{\prime}\left(\delta_{H} 1.50\right)$ to $\mathrm{C}-5^{\prime} / \mathrm{C}-6^{\prime} / \mathrm{C}-15^{\prime}$. The NOESY correlation of $\mathrm{H}-10^{\prime}$ with $\mathrm{H}-12^{\prime}$ suggested that the geometry of $\Delta^{10^{\prime}, 11^{\prime}}$ double bond was trans.

The small optical rotation value and similar Cotton effects in the ECD spectrum of the mix of 3 and 4 compared with those of 1 and 2 inferred that it was likely an enantiomeric mixture. The chiral HPLC purification afforded the enantiomers 3 and 4 in a ratio of approximately 1:1 (Figure 2). The ECD spectrum of 3 showed negative and positive Cotton effects at 208 and $250 \mathrm{~nm}$, respectively, suggesting a 1 'R-configuration. Conversely, its enantiomer 4 should be 1 'S. Therefore, 
the structures of compounds 3 and 4 were concluded as (5R)-3-\{9-[(E)-coumaroyl]-4- hydroxymethyl-8-methyl7-nonene $\}-5-(2,5$-dihydroxyphenyl)-2(5H)-furanone and $(5 S)-3-\{9-[(E)$-coumaroyl]-4-hydroxymethyl-8-methyl-7nonene -5 - (2,5-dihydroxyphenyl)-2(5H)-furanone, and named ganosinensol $\mathrm{G}$ and ganosinensol $\mathrm{H}$, respectively.

The molecular formula of 5 and 6 were established as $\mathrm{C}_{31} \mathrm{H}_{36} \mathrm{O}_{9}$, on the basis of ${ }^{13} \mathrm{C}$ NMR spectroscopic and HRESIMS data $[\mathrm{M}+\mathrm{Na}]^{+}$at $m / z 575.2261$ (calcd 575.2257). The difference between $5 / 6$ and $3 / 4$ was the missing of $\delta_{C} 80.0\left(\mathrm{C}-1^{\prime}\right)$ and the appearance of $\delta_{C}$ $106.5 / 51.0$ in 5 and 6 (Table 1), speculating the linkage of a methoxyl to $\mathrm{C}-1^{\prime}\left(\delta_{C} 106.5\right)$. The HMBC correlations (Figure 1b) of $1^{\prime}-\mathrm{OCH}_{3}\left(\delta_{H} 3.16\right)$ with $\mathrm{C}-1^{\prime}\left(\delta_{C} 106.5\right)$, and H-2' $\left(\delta_{H} 7.38\right)$ with $\mathrm{C}-1^{\prime}\left(\delta_{C} 106.5\right)$, confirmed the above supposition. The geometry of $\Delta^{10^{\prime}, 11^{\prime}}$ double bond was determined as trans based on the NOESY correlation of $\mathrm{H}-10^{\prime}$ with $\mathrm{H}-12^{\prime}$.

Although the mix of compounds 5 and 6 showed measurable optical rotations $\left([\alpha]_{D}^{20}-10\right)$, its enantiomeric nature was demonstrated by chiral HPLC. The chiral HPLC purification afforded enantiomers 5 and 6 in a ratio of approximately 1:1 (Figure 2). The enantiomers also displayed typical antipodal ECD curves and opposite specific rotations. The absolute configurations of 5 and 6 were determined as $1^{\prime} R$ and $1^{\prime} S$, respectively, using the same methods as described in 1 and 2 . The combined data established the structures of 5 and 6 as $(5 R)-3-\{9-$ $[(E)$-coumaroyl]-4-hydroxymethyl- 8-methyl-7-nonene $\}$ 5-(2,5-dihydroxyphenyl)-5-methoxy-2(5H)-furanone and $(5 S)-3-\quad\{[9-[(E)$-coumaroyl $]-4-h y d r o x y m e t h y l-8-$ methyl-7-nonene -5 -(2,5-dihydroxyphenyl) -5-methoxy-

a
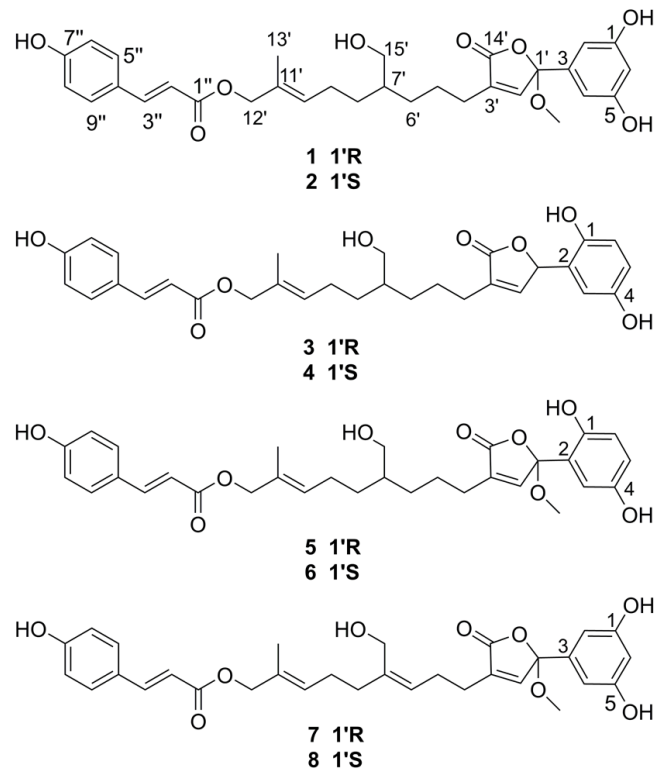

2(5H)-furanone, which were named ganosinensol I and ganosinensol J, respectively.

\section{Structure based virtual ligand screening}

The eight isolated farnesyl phenolic compounds (18) were screened against the MTH1 model in silico based on its X-ray structure (PDB code: 4C9X) [8] during the preliminary evaluation. Compounds with lower calculated binding energies were considered to have higher binding affinities for the target. The results predicted that these farnesyl phenolic compounds exhibited the high binding affinity to MTH1 with negative mfScores of -163.4 215.1 (Table 2). From the generated docking model, these kind of compounds were adopted a folded conformation, which occupied the active site of the enzyme, hydrogen bonds were predicted between 15'-hydroxyl group and carbonyl group of Thr8, 1-hydroxyl group and carbonyl group of Asn33, as well as between 7"-hydroxyl group and carboxyl group of Glu77. Also, compound 1 formed key hydrophobic interactions between 1'-benzene ring and side chain of Lys23, and between furan ring and Tyr7. The $\pi-\pi-\pi$ stacking interaction formed by 3 "-benzene ring with Phe27 and Phe74, further strengthens the binding (Figure 3).

\section{Specific binding with MTH1 in vitro}

To validate the finding of the virtual ligand screening, we expressed the recombinant protein of human MTH1 [9]. Microscale thermophoresis method (MST) was employed to assay the binding affinity between the compounds and MTH1. This technology can quantify
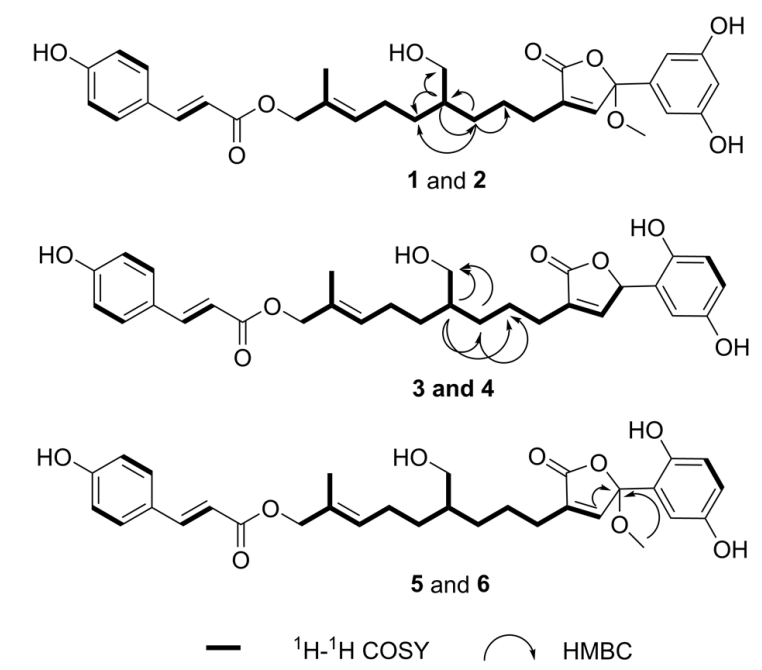

Figure 1: Chemical structures of the eight farnesyl phenolic compounds. (a) Structures of compounds $1-8$. (b) Key $\mathrm{H}^{1}-\mathrm{H}^{1}$ COSY and HMBC correlations of compounds 1-6. 
Table 1: ${ }^{1} \mathrm{H}$ and ${ }^{13} \mathrm{C}$ NMR spectroscopic data for compounds $1-6^{a}$

\begin{tabular}{|c|c|c|c|c|c|c|}
\hline \multirow{2}{*}{ Position } & \multicolumn{2}{|c|}{1 and $2^{b}$} & \multicolumn{2}{|c|}{3 and $4^{b}$} & \multicolumn{2}{|c|}{5 and $6^{c}$} \\
\hline & $\delta_{C}$, type & $\delta_{H}(J$ in $\mathrm{Hz})$ & $\delta_{c}$, type & $\delta_{H}(J$ in $\mathrm{Hz})$ & $\delta_{c}$, type & $\delta_{H}(J$ in $\mathrm{Hz})$ \\
\hline 1 & $151.4, \mathrm{C}$ & & 149.1, C & & $147.4, \mathrm{C}$ & \\
\hline 2 & $118.5, \mathrm{CH}$ & 6.67 , br s & 123.6, C & & 122.0, C & \\
\hline 3 & 123.6, C & & $113.5, \mathrm{CH}$ & $6.47, \mathrm{~d}(2.8)$ & $113.2, \mathrm{CH}$ & $6.87, \mathrm{~d}(2.8)$ \\
\hline 4 & $118.4, \mathrm{CH}$ & 6.67, br s & $151.6, \mathrm{C}$ & & 149.6, C & \\
\hline 5 & 149.4, C & & $117.4, \mathrm{CH}$ & $6.60, \mathrm{dd}(8.6,2.8)$ & $117.0, \mathrm{CH}$ & $6.61, \mathrm{dd}(8.4,2.8)$ \\
\hline 6 & $114.8, \mathrm{CH}$ & 6.94 , br s & $117.4, \mathrm{CH}$ & $6.67, \mathrm{~d}(8.6)$ & $117.1, \mathrm{CH}$ & $6.66, \mathrm{~d}(8.4)$ \\
\hline $1^{\prime}$ & 108.7, C & & $80.0, \mathrm{CH}$ & 6.23 , br s & $106.5, \mathrm{C}$ & \\
\hline $2^{\prime}$ & $147.9, \mathrm{CH}$ & 7.40 , br s & 151.0, $\mathrm{CH}$ & 7.35 , br s & $145.9, \mathrm{CH}$ & $7.38, \mathrm{~d}(1.0)$ \\
\hline $3^{\prime}$ & 136.7, C & & 133.7, C & & 134.9, C & \\
\hline $4^{\prime}$ & 26.3, $\mathrm{CH}_{2}$ & $2.27, \mathrm{t}(6.8)$ & $26.4, \mathrm{CH}_{2}$ & $2.30, \mathrm{t}(7.2)$ & $24.8, \mathrm{CH}_{2}$ & $2.20, \mathrm{t}(7.6)$ \\
\hline $5^{\prime}$ & 25.9, $\mathrm{CH}_{2}$ & $1.59, \mathrm{~m}$ & 26.1, $\mathrm{CH}_{2}$ & $1.61, \mathrm{~m}$ & $24.2, \mathrm{CH}_{2}$ & $1.49, \mathrm{~m}$ \\
\hline $6^{\prime}$ & $31.5, \mathrm{CH}_{2}$ & $1.31, \mathrm{~m}$ & $31.6, \mathrm{CH}_{2}$ & $1.43, \mathrm{~m}$ & $30.0, \mathrm{CH}_{2}$ & $1.22, \mathrm{~m}$ \\
\hline $7^{\prime}$ & $41.0, \mathrm{CH}$ & $1.47, \mathrm{~m}$ & $41.1, \mathrm{CH}$ & $1.50, \mathrm{~m}$ & $39.4, \mathrm{CH}$ & $1.37, \mathrm{o}$ \\
\hline $8^{\prime}$ & $31.7, \mathrm{CH}_{2}$ & $1.40, \mathrm{~m}$ & $31.7, \mathrm{CH}_{2}$ & $1.34, \mathrm{~m}$ & $30.3, \mathrm{CH}_{2}$ & $1.36, \mathrm{o}$ \\
\hline $9^{\prime}$ & 26.1, $\mathrm{CH}_{2}$ & $2.06, \operatorname{td}(7.2,7.2)$ & $26.2, \mathrm{CH}_{2}$ & $2.08, \mathrm{~m}$ & $24.5, \mathrm{CH}_{2}$ & $1.98, \operatorname{td}(7.6,7.2)$ \\
\hline $10^{\prime}$ & $130.8, \mathrm{CH}$ & $5.49, \mathrm{t}(6.6)$ & $130.8, \mathrm{CH}$ & 5.50 , br s & 129.1, CH & $5.46, \mathrm{t}(6.8)$ \\
\hline $11^{\prime}$ & 131.7, C & & 131.7, C & & 129.9, C & \\
\hline $12^{\prime}$ & $71.2, \mathrm{CH}_{2}$ & 4.55 , br s & $71.2, \mathrm{CH}_{2}$ & 4.55, br s & $69.0, \mathrm{CH}_{2}$ & 4.50, br s \\
\hline 13' & $14.3, \mathrm{CH}_{3}$ & $1.68, \mathrm{~s}$ & $14.3, \mathrm{CH}_{3}$ & $1.69, \mathrm{~d}(3.7)$ & $13.7, \mathrm{CH}_{3}$ & $1.61, \mathrm{~s}$ \\
\hline $14^{\prime}$ & $173.6, \mathrm{C}$ & & 176.9, C & & 171.0, C & \\
\hline $15^{\prime}$ & $65.4, \mathrm{CH}_{2}$ & 3.46, br d (3.7) & $65.5, \mathrm{CH}_{2}$ & 3.48, br d (4.8) & $63.0, \mathrm{CH}_{2}$ & 3.29, br d (4.4) \\
\hline $1 "$ & 169.3, C & & 169.3, C & & $166.4, \mathrm{C}$ & \\
\hline $2^{\prime \prime}$ & $115.3, \mathrm{CH}$ & 6.33, d (15.6) & $115.4, \mathrm{CH}$ & $6.33, \mathrm{~d}(16.0)$ & $114.0, \mathrm{CH}$ & $6.40, \mathrm{~d}(16.0)$ \\
\hline 3" & $146.7, \mathrm{CH}$ & $7.60, \mathrm{~d}(15.6)$ & 146.7, CH & $7.60, \mathrm{~d}(16.0)$ & 144.7, CH & $7.55, \mathrm{~d}(16.0)$ \\
\hline $4^{\prime \prime}$ & 127.3, C & & 127.3, C & & $124.9, \mathrm{C}$ & \\
\hline 5"9" & $131.3, \mathrm{CH}_{2}$ & $7.45, \mathrm{~d}(8.4)$ & $131.3, \mathrm{CH}_{2}$ & $7.45, \mathrm{~d}(8.6)$ & $130.3, \mathrm{CH}_{2}$ & $7.54, \mathrm{~d}(8.4)$ \\
\hline 6"8" & 117.0, $\mathrm{CH}_{2}$ & $6.80, \mathrm{~d}(8.4)$ & $117.0, \mathrm{CH}_{2}$ & $6.79, \mathrm{~d}(8.6)$ & $115.8, \mathrm{CH}_{2}$ & $6.78, \mathrm{~d}(8.4)$ \\
\hline $7^{\prime \prime}$ & $161.4, \mathrm{C}$ & & $161.4, \mathrm{C}$ & & $160.0, \mathrm{C}$ & \\
\hline $\mathrm{OCH}_{3}$ & $52.3, \mathrm{CH}_{3}$ & $3.27, \mathrm{~s}$ & & & $51.0, \mathrm{CH}_{3}$ & $3.16, \mathrm{~s}$ \\
\hline
\end{tabular}

${ }^{a 1} \mathrm{H}$ NMR, $400 \mathrm{MHz} ;{ }^{13} \mathrm{C}$ NMR, $100 \mathrm{MHz}$. The assignments were based on HSQC and HMBC experiments. The ${ }^{1} \mathrm{H}$ and ${ }^{13} \mathrm{C}$ NMR data were identical for each pair of enantiomers.

${ }^{b}$ Measured in $\mathrm{CD}_{3} \mathrm{OD}$.

${ }^{c}$ Measured in DMSO- $d_{6}$.

protein-protein interactions or protein-small molecule interactions with high sensitivity through detecting fluorescent changes of molecules during thermophoresis [32]. Among all the tested compounds, ganosinensols $\mathrm{E}$ (1) and F (2) exhibited the strongest binding with MTH1
(Table 2 and Figure 4). The equilibrium dissociation constants (Kd) of ganosinensols E (1) and F (2) were 4.71 and $2.38 \mu \mathrm{M}$, respectively. Further enzyme inhibition experiments showed that ganosinensols E (1) and F (2) could significantly inhibit the activity of MTH1 in vitro 
with $\mathrm{IC}_{50}$ of 10.92 and $10.95 \mu \mathrm{M}$, respectively (Table 2). Besides, compounds 3-8 also showed certain binding affinities to MTH1 and inhibitory activities (Table 2).

\section{Farnesyl phenolic compounds showed inhibitory effects on cancer cells and induced apoptosis}

The growth inhibitory effects of the isolated farnesyl phenolic compounds (1-8) against carcinoma cell lines [human osteosarcoma cells (U2OS), human colorectal carcinoma cells (SW620), human ES-2 ovarian carcinoma cells (ES-2)] and normal tissue cell lines [human hepatic cells (Lo2), African green monkey kidney vero cells (Vero)] were further investigated using CCK8 assay method (Table 3). All of these compounds showed potential antitumor activity against the tested cell lines with $\mathrm{IC}_{50}$ values of $45.0 \sim 111.4 \mu \mathrm{M}$, slightly weaker than that of the positive control $(S)$-crizotinib. Noteworthily, the much higher $\mathrm{IC}_{50}$ values (most of them more than 300 $\mu \mathrm{M})$ of these compounds on normal tissue cells indicated that they induced cell growth inhibition obviously in tumor cells and without significant cytotoxicity toward normal human cells, showing their better selectivity than $(S)$-crizotinib intracellularly.

The apoptosis of cells induced by compounds was further investigated. SW620 cells were pretreated with series concentration of compound 1 for 24 hours. The number of apoptosis cells was quantified by flow cytometry. The ratio of apoptotic cells increased in compound 1 treated group in dose-dependent manner, with $45.09 \%$ and $91.11 \%$ SW620 cells apoptotic death at 50
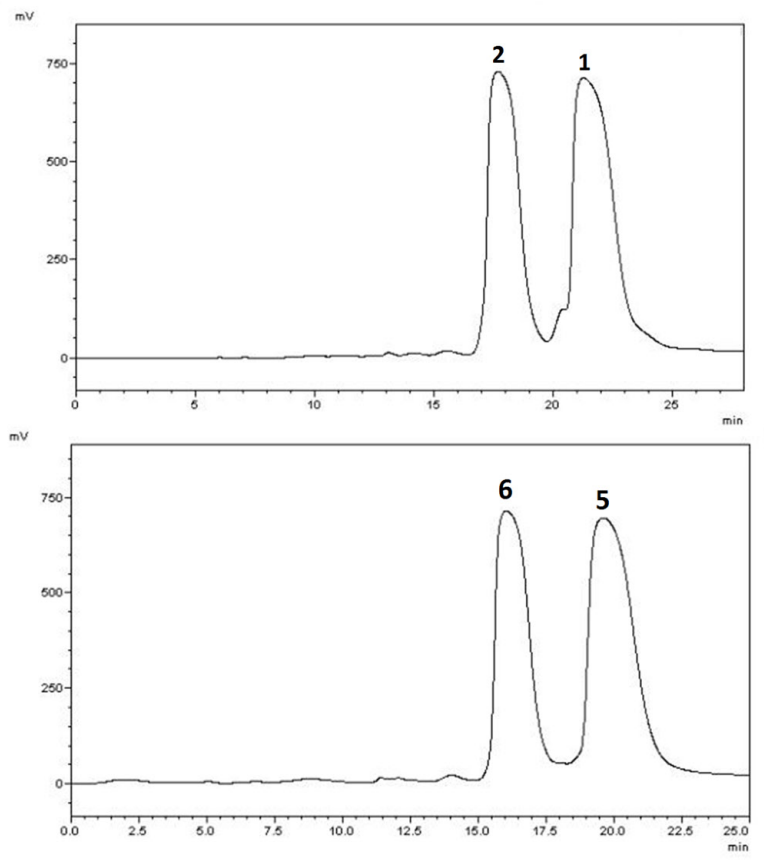

$\mu \mathrm{M}$ and $150 \mu \mathrm{M}$ of compound 1 , respectively, compared with $12.03 \%$ for the control group (Figure 5A).

\section{Compound 1 induced DNA damage and hindered the replication of DNA in cancer cells}

EdU cell proliferation assay and 53BP1 foci were performed here, demonstrating that farnesyl phenolic compounds could induce DNA damage and hinder the replication of DNA in cancer cells. EdU cell proliferation assays were carried out to detect the effects of compounds on DNA replication. EdU (5-Ethynyl-2- deoxyuridine), a thymidine analog, can penetrate into the replicating DNA molecule. Based on the specific response of EdU and fluorescent dyes, DNA replication activity could be detected. Results showed that the percentage of EdU ${ }^{+}$cells significantly deceased when treated by compound 1 at theconcentration of $50 \mu \mathrm{M}$ or $150 \mu \mathrm{M}$ compared with the control (Figure $5 \mathrm{~B}$ and $5 \mathrm{C}, \mathrm{P}<0.001$ ). The phenomenon proved precisely that compound 1 caused disruption of DNA replication (Figure 5B and 5C).

Meanwhile, MTH1 could prevent the mispairing of bases during replication and transversion mutations $[5,6]$. Presumably, its inhibitors could cause DNA damage. P53 binding protein 1 (p53-binding, protein $1,53 \mathrm{BP} 1)$ is an important regulatory factor in response to double strand breaks. The results showed that 53BP1 was significantly aggregated after treated with compound 1 compared to control, indicating the damage of DNA (Figure 5D-5F, $\mathrm{P}<0.01)$.
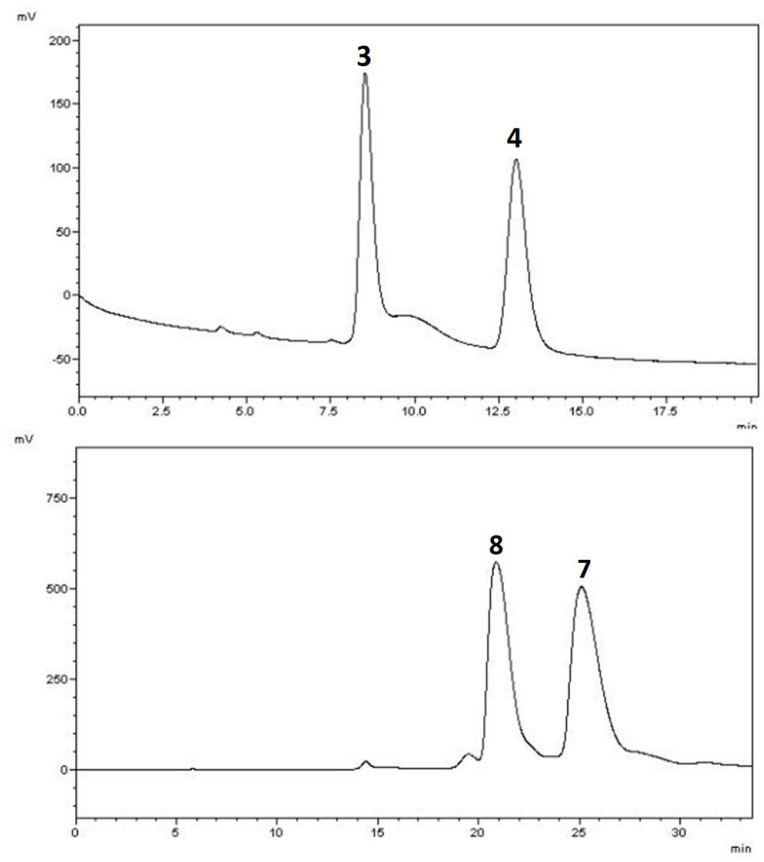

Figure 2: Chiral HPLC separation profiles of 1-8. 
Table 2: Binding affinity and inhibitory activities of 1-8 against MTH1 enzyme in vitro

\begin{tabular}{|c|c|c|c|}
\hline \multirow{2}{*}{ No. } & \multirow{2}{*}{ mfScores (kcal/mol) } & \multicolumn{2}{|c|}{ МТН1 } \\
\hline & & $\mathbf{K d}(\boldsymbol{\mu M})$ & $\mathrm{IC}_{50}(\mu \mathrm{M})$ \\
\hline 1 & -215.1 & $4.710 \pm 0.686$ & $10.92 \pm 1.04$ \\
\hline 2 & -182.9 & $2.380 \pm 0.663$ & $10.95 \pm 1.03$ \\
\hline 3 & -180.4 & $246.0 \pm 38.7$ & $22.90 \pm 1.04$ \\
\hline 4 & -187.5 & $4.630 \pm 0.519$ & $22.89 \pm 1.07$ \\
\hline 5 & -173.2 & $296.0 \pm 13.3$ & $16.33 \pm 1.03$ \\
\hline 6 & -163.4 & $113.0 \pm 25.4$ & $8.62 \pm 1.03$ \\
\hline 7 & -200.8 & $103.0 \pm 32.1$ & $28.48 \pm 1.05$ \\
\hline 8 & -202.3 & $210.0 \pm 42.7$ & $26.60 \pm 1.03$ \\
\hline$(S)$-crizotinib ${ }^{a}$ & N.P. ${ }^{b}$ & $0.018 \pm 0.002$ & $0.88 \pm 1.51$ \\
\hline
\end{tabular}

${ }^{a}(S)$-crizotinib was used as positive control.

${ }^{b}$ N.P. represents mfScores of $(S)$-crizotinib was not performed.

\section{Compound 1 interacted with MTH1 in cells}

In order to study whether the cytotoxicity of the farnesyl phenolic compounds was due to the inhibition of MTH1, the expression of endogenous MTH1 was knocked down in cancer cells. SW620 cell lines were transfected with MTH1 siRNA (\#1, \#2 and \#3), [2] while the control was transfected with non-targeting siRNA (NT). The expression levels of MTH1 were measured by Western blot assay (Figure 6A and 6B), both siRNA \#2 and \#3 knocked down expressions of MTH1 in SW620 cells. The effects of compound 1 on the growth of MTH1
siRNA (\#2 and \#3) and non-targeting siRNA transfected cells were assessed by CCK 8 assay. Results indicated that cells infected with MTH1 siRNA were resistant to the growth inhibition caused by compound 1 compared with non-targeting siRNA transfected cells (Figure 6C). Just as normal cells which do not need MTH1 (Figure 6D), survival cancer cells infected with MTH1 siRNA were insensitive to compound 1 . These findings suggested that inhibitory activities induced by compound 1 were dependent on the MTH1 expression.

The cellular thermal shift assay (CETSA) was recently developed to further confirm the interaction

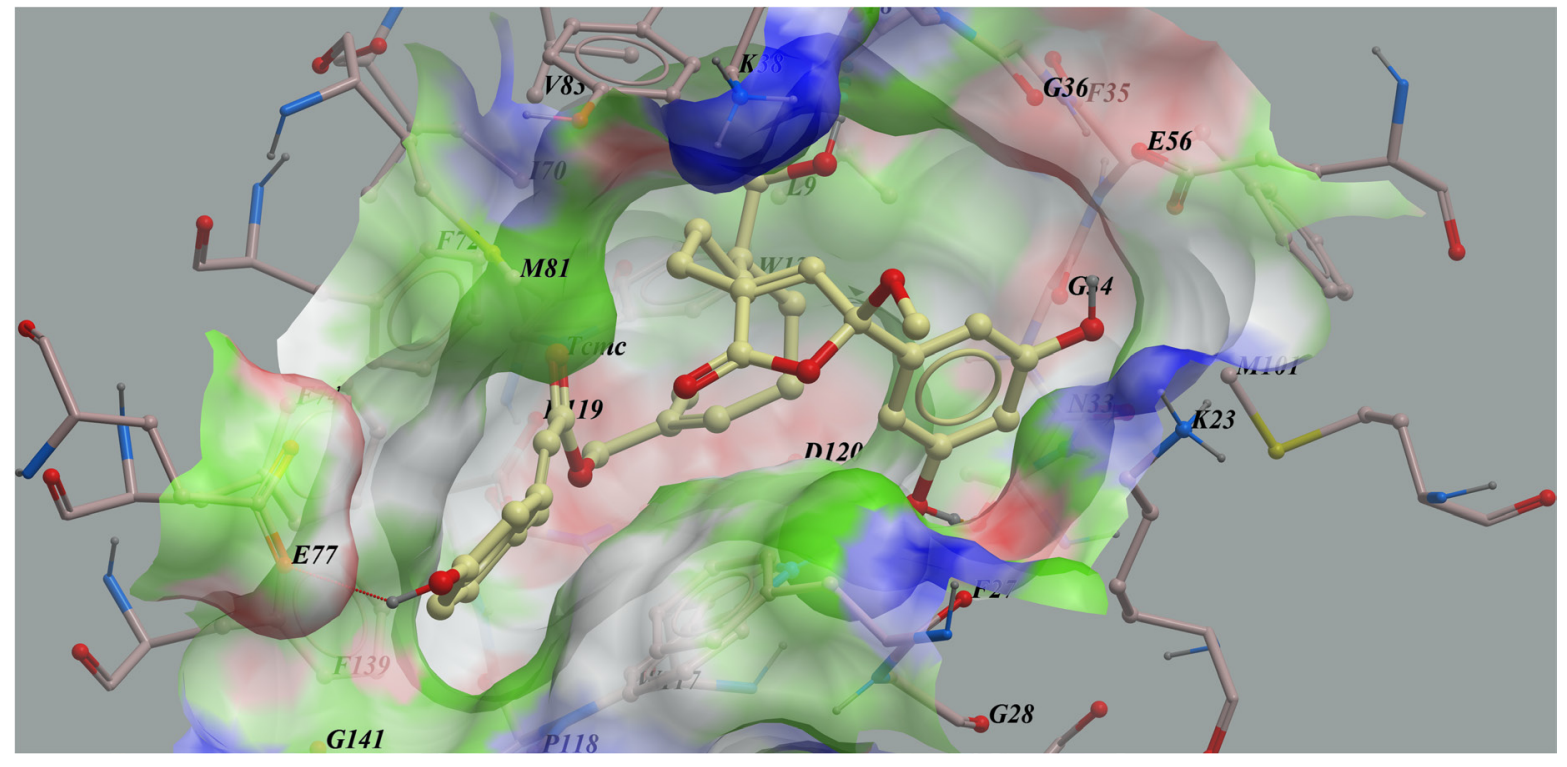

Figure 3: Low-energy binding conformations of compound 1 bound to MTH1 generated by virtual ligand docking. Compound 1 depicted as the ball-and-stick model showing carbon (yellow), hydrogen (grey) and oxygen (red) atoms. Compounds were observed to occupy the active site of the enzyme and adopted a conformation similar to that of known inhibitors. 
Table 3: $\mathrm{IC}_{50}$ values $^{a}(\mu \mathrm{M})$ of compounds 1-8 against carcinoma and normal tissue cell lines

\begin{tabular}{lcccccc}
\hline & Carcinoma cell lines & \multicolumn{3}{c}{$\begin{array}{c}\text { Normal tissue cell } \\
\text { lines }\end{array}$} \\
\cline { 1 - 1 } No. & U2OS & SW620 & ES-2 & Lo2 & Vero \\
\hline 1 & $111.40 \pm 1.29$ & $45.02 \pm 1.23$ & $55.50 \pm 1.08$ & $150.30 \pm 1.09$ & $>300$ \\
2 & $54.24 \pm 1.10$ & $103.80 \pm 1.07$ & $76.78 \pm 1.09$ & $>300$ & $260.40 \pm 1.16$ \\
3 & $73.19 \pm 1.24$ & $70.93 \pm 1.08$ & $90.58 \pm 1.12$ & $>300$ & $>300$ \\
4 & $66.44 \pm 1.11$ & $56.46 \pm 1.15$ & $64.24 \pm 1.28$ & $279.10 \pm 2.17$ & $>300$ \\
5 & $64.40 \pm 1.08$ & $61.80 \pm \pm 1.06$ & $80.13 \pm 3.56$ & $>300$ & $>300$ \\
6 & $57.79 \pm 1.07$ & $53.72 \pm 1.06$ & $37.26 \pm 3.56$ & $>300$ & $>300$ \\
7 & $96.30 \pm 1.13$ & $100.70 \pm 1.07$ & $74.45 \pm 1.17$ & $>300$ & $>300$ \\
8 & $95.36 \pm 1.05$ & $55.21 \pm 1.16$ & $60.88 \pm 1.34$ & $>300$ & $>300$ \\
$(S)-C^{b}$ & $32.28 \pm 1.28$ & $17.50 \pm 1.11$ & $9.09 \pm 1.06$ & $26.01 \pm 1.20$ & $16.69 \pm 1.15$ \\
\hline
\end{tabular}

${ }^{a} \mathrm{IC}_{50}$ values of the isolated compounds were obtained from the mean $\mathrm{OD}$ values of the triplicate tests versus the drug concentration curves.

${ }^{b}(S)$-C represents $(S)$-crizotinib, which was used as positive control.

between the target and the compound in vitro by Western blot assay. CETSA was applied based on the principles that the ligand binding gave rise to the thermal stabilization of target proteins. The thermal stability of MTH1 in SW620 cells was tested at the temperature range of 44$54^{\circ} \mathrm{C}$ after the pretreatment of compound 1 for 12 hours (Figure 6E and 6F). Correspondingly, the control cells were treated with DMSO. The results showed that MTH1 protein was still clearly detectable for the group pretreated with compound 1, but not for the DMSO treated group. Compared with the control group, the thermal stability of MTH1 protein in compound 1 pretreated cells was better under the same temperature condition. This suggested that the specific binding of compound 1 to the MTH1 protein in SW620 cells.

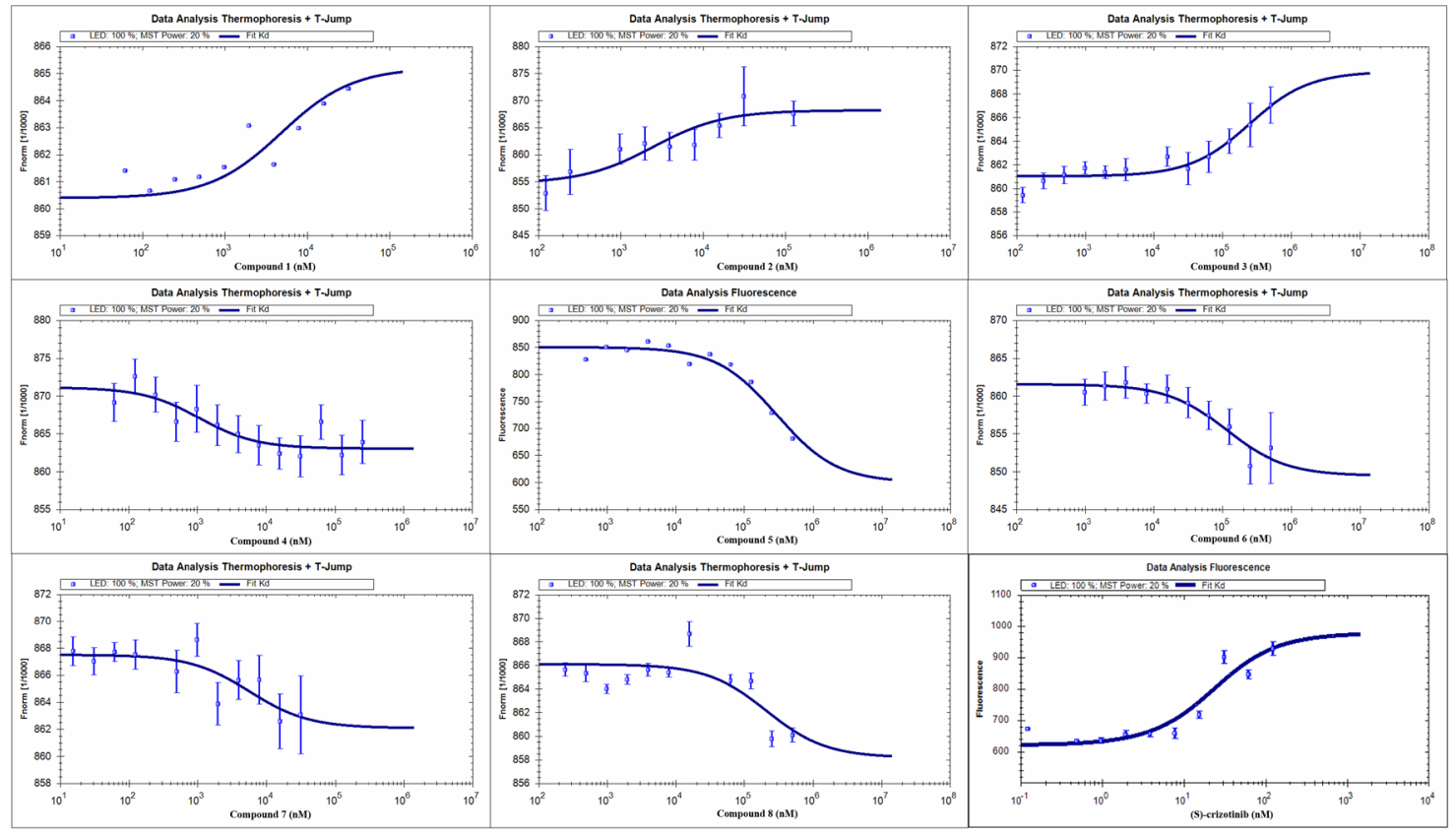

Figure 4: MST assay confirmed the specific binding of compounds 1-8 and (S)-crizotinib to MTH1. Measurement of affinity between compounds with MTH1 was carried out by MST in triple. The dissociation constant Kd values were automatically calculated by using the NT Analysis software (Nano Temper Technologies, München, Germany). 


\section{DISCUSSION}

In summary, this paper describes the isolation, chiral resolution and structure elucidation of four pairs of new farnesyl phenolic stereo isomers (1-8), from the fruiting bodies of $G$. sinense. The absolute configurations of
$\mathrm{C}-1^{\prime}$ in the new enantiomers $1-6$ were assigned by ECD spectra. The farnesyl phenols possessing a coumaroyl substitution have rarely been encountered in nature [31].

Structure-based virtual ligand screening was applied to discover small-molecule MTH1 inhibitors in early stage. As a result, the eight farnesyl phenols were found
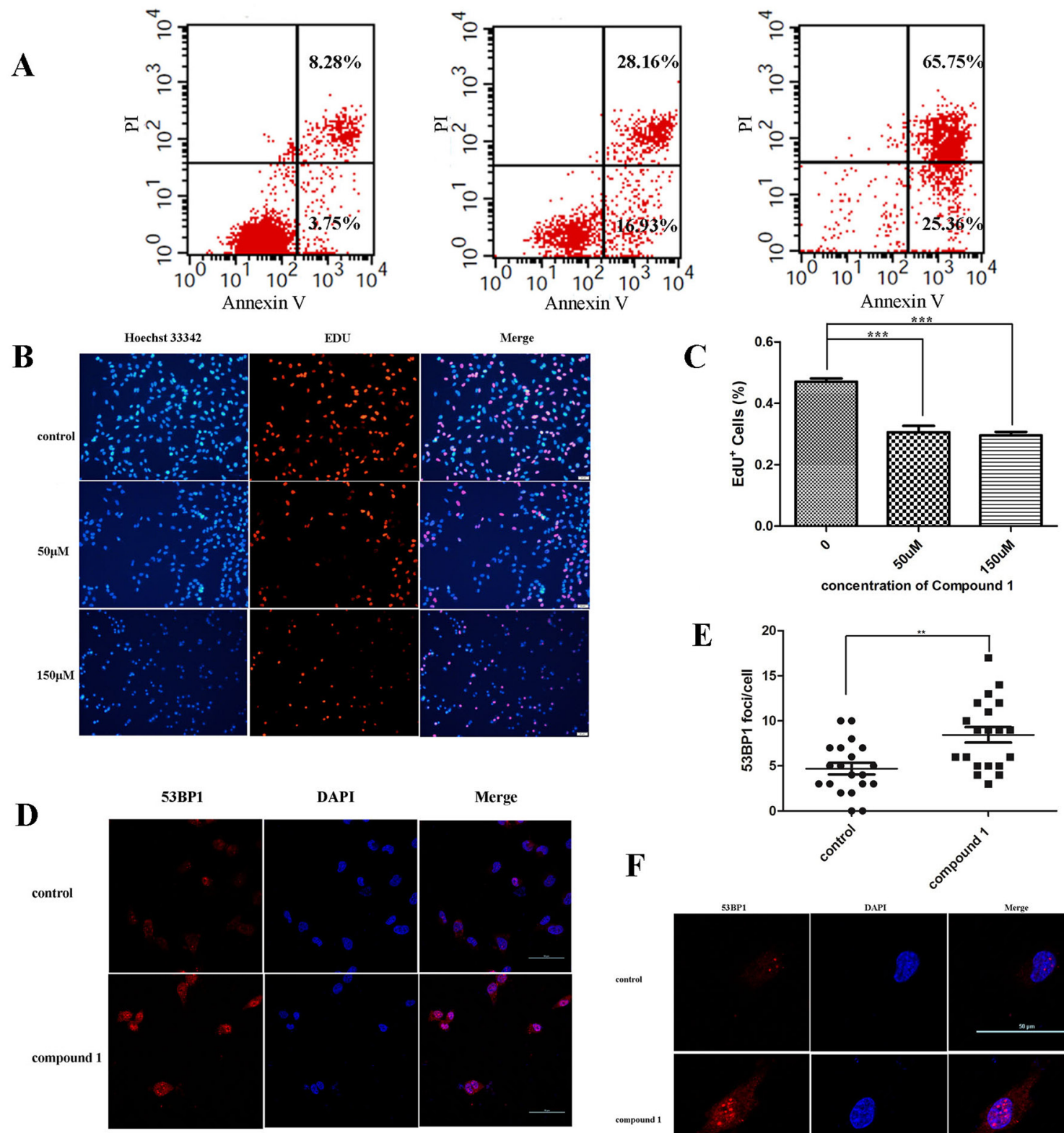

F
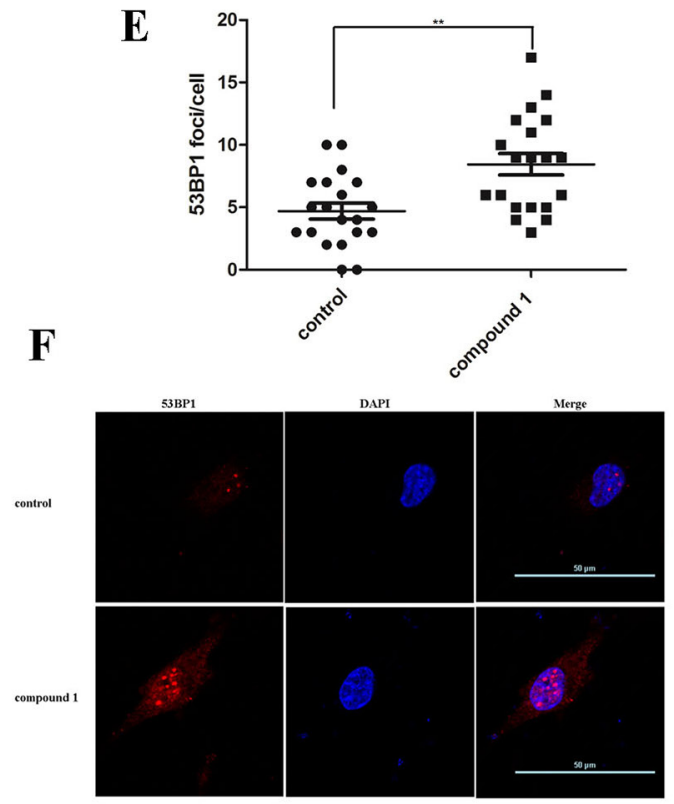

Figure 5: Compound 1 induced DNA damage and hindered the replication of DNA in cancer cells causing cell apoptosis. (A) SW620 cells were treated with 0,50 or $150 \mu \mathrm{M}$ of compound 1 and then processed for FACS by using Annexin V/propidium iodide staining. (B, C) Immunofluorescence staining analysis of $\mathrm{EDU}^{+}$and quantification of EDU ${ }^{+}$in SW620 cells treated with 0,50 or $150 \mu \mathrm{M}$ of compound 1. Stained graphs were observed through a fluorescence microscope $(\times 200$ magnification $)$. Bar $=20 \mu \mathrm{m}$. Data are shown as mean \pm s.d. $(\mathrm{n}=3)$. (D, E, F) Immunofluorescence staining analysis of 53BP1 and quantification of 53BP1 foci formation in SW620 treated for $24 \mathrm{~h}$ with $50 \mu \mathrm{M}$ of compound 1. It was observed through a confocal microscope ( $\times 400$ magnification $)$. Bar $=50 \mu \mathrm{m}$ Data are shown as mean \pm s.d. $(\mathrm{n}=3)$. 
from a small in-house database of natural products through the above method. MST assays validated the results of virtual screening and quantitatively measured the affinity between candidates (compounds 1-8) and MTH1 protein. Subsequently, enzymatic and cell-based assays confirmed ganosinensols E (1) and F (2) as a potential inhibitor of MTH1.

The dysfunctional redox regulation led to the production of reactive oxygen species, causing damage to DNA and free dNTPs. The MTH1 protein that could clean up oxidized dNTP such as 8-oxo-dGTP or 2-OHdATP, prevents incorporation of damaged bases during
DNA replication to ensure the survival of cancer cells [4, 8]. Nevertheless, the dysfunctional redox regulation was not observed in normal cells. Thus, MTH1 protein played an important role to maintain tumor cell survival, while it was dispensable for the growth of normal cells. Structurebased virtual ligand screening and MST assays confirmed the specific binding between MTH1 protein and farnesyl phenolic compounds. In agreement with the prediction, the cytotoxicity assay results showed the different effects of farnesyl phenolic compounds on normal cells and cancer cells. These farnesyl phenolic compounds could inhibit the growth of various human cancer cells, while
A

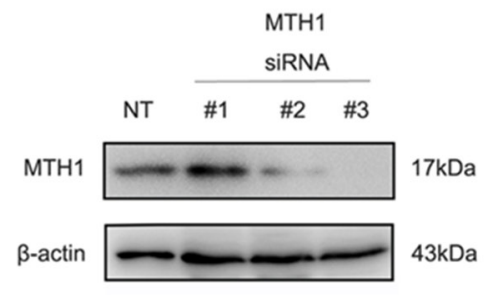

B

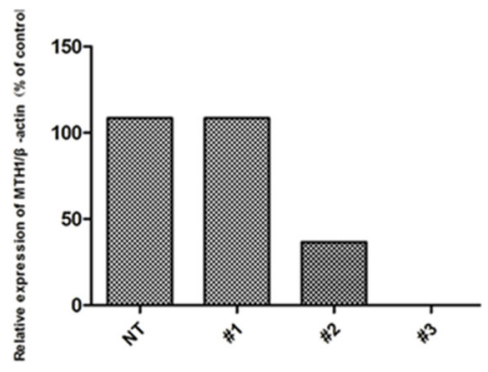

$\mathrm{C}$

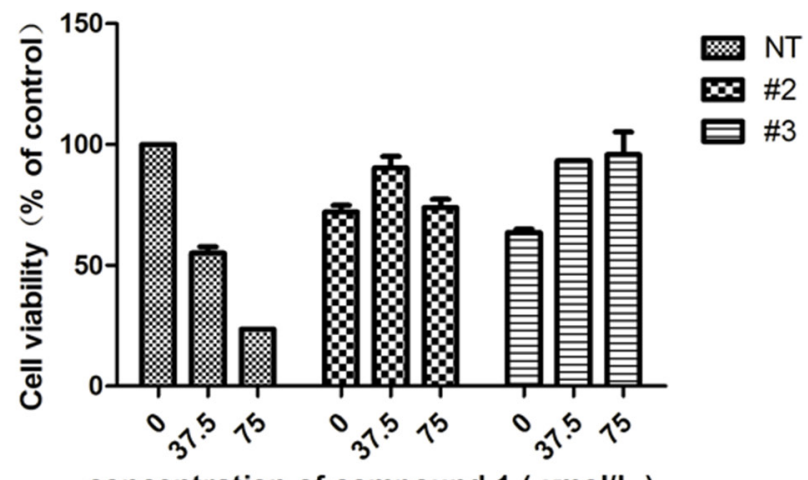

concentration of compound 1 ( $\mu \mathrm{mol} / \mathrm{L}$ )

D

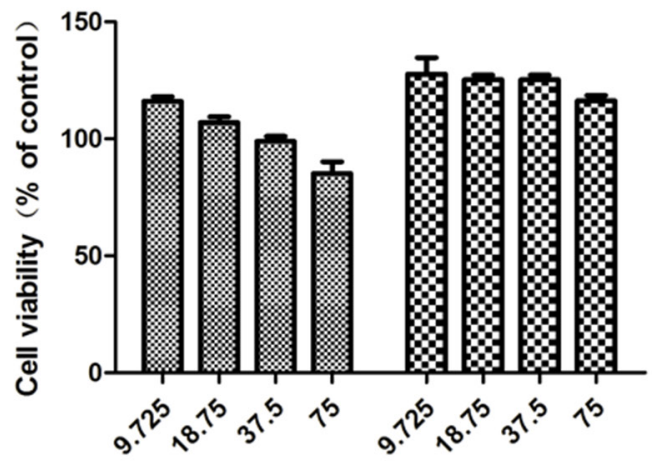

concentration of compound 1 ( $\mu \mathrm{mol} / \mathrm{L}$ )

$\mathbf{F}$
$\mathbf{E}$

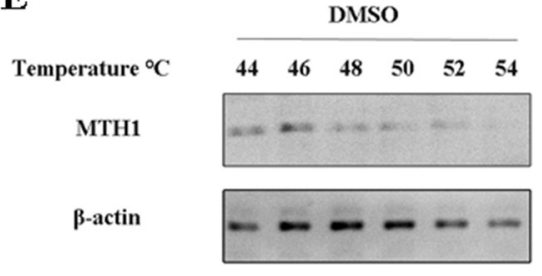

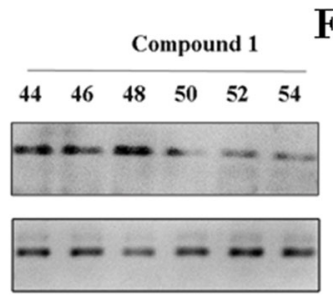

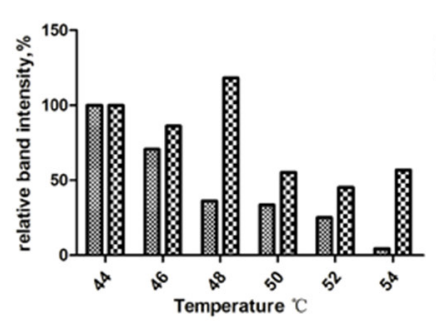

Figure 6: The specific binding of compound 1 to the MTH1 protein leads to cell growth inhibition. (A, B) Western blot analysis and optical density analysis for the expression of MTH1 for the siRNA transfected cells. MTH1 siRNA \#2 and \#3 were both knocked down in SW620 cells compared with the non-target siRNA (NT). (C) The effects of compound 1 on the growth of MTH1 siRNA (\#2 and \#3) and non-targeting siRNA transfected cells were assessed by CCK8 assay. Results suggested that anticancer activities induced by compound 1 were dependent on the MTH1 in cells. (D) The effects of compounds 1 on normal tissue cell lines [human hepatic cells (Lo2), African green monkey kidney vero cells (Vero)]. (E, F) Cellular thermal shift assay (CETSA) confirmed the binding capacity of compound 1 with MTH1 at the cellular level. It is predictable that the specific binding of compound 1 to the MTH1 protein in SW620 cells. 
no obvious cytotoxicity was found on normal tissue cell lines, showing their features of selectivity and security as a potential candidate drug. And there was no notable difference on antitumor activity between each pair of stereo isomers, showing that the configuration of the chiral center is not vital for their activity. All these tend to imply that farnesyl phenolic compounds, especially for ganosinensols E (1) and F (2), are at least good lead compounds for designing novel MTH1 inhibitors. And it was also found that compound 1 induced DNA damage and hindered the replication of DNA in SW620 cells. Furthermore, siRNA knock down experiments and the CETSA were carried out to confirm the interaction between compound 1 and MTH1 in SW620 cells. Results implied that the farnesyl phenolic compounds specifically targeted MTH1 proteins in cells. Moreover, especially for siRNA knock down experiments, the toxic effect of the compound 1 was reduced after knockdown of MTH1 in cells. It did prove that the interaction between compound 1 and MTH1 was critical for its cytotoxicity. The project also suggested that the virtual ligand screening method is a useful tool to discover active lead compounds from natural products.

In this study, we chose $(S)$-crizotinib as the positive control for following reasons. $(S)$-crizotinib, was an effective inhibitor of MTH1 according to the relevant research $[4,8]$. $(S)$-crizotinib was proved to be a MTH1 inhibitor by more technical means (MTH1 catalytic activity inhibition assays, ITC assays, etc) compared to other inhibitors, such as TH287 and TH588 with almost the similar binding affinity to MTH1 as $(S)$-crizotinib. In addition, $(S)$-crizotinib was the ligand of the co-crystal structure of MTH1 (PDB code: 4C9X) which was chosen as the template to generate our model to perform virtual ligand screening. This allowed the consistence for our research. Therefore, $(S)$-crizotinib is more reliable and suitable as the positive control compared to other chemical inhibitors.

While some recent articles reported that MTH1 may not be an independent anti-cancer target, [33-35] there is no doubt that MTH1 is a target of cellular antioxidative defenses [1, 36-38]. For both normal and cancerous cells, it is not uncommon that different cells have different sensitivities to MTH1 inhibitor. There were many factors, which influence effects of MTH1 inhibitors on the growth of cancer cells. For cancer cells with strong anti-oxidative defense, MTH1 inhibitor has no cytotoxicities. In contrast, MTH1 inhibitors have strong killing potency for cancer cells that have weak resistance to oxidative stress. It was reported that the disruption of MTH1 increased telomere dysfunctions and caused cancer cell deaths [1]. Thus cancer cells with shorten telomere would be more sensitive to MTH1 inhibition and the oxidative stress [1]. The inhibition or disruption of MTH1 is sure to reduce the cell's ability to cope with oxidative stress, especially for cancer cells $[1-4,36]$. MTH1, which protects cancer cells from the oxidative-stress-induced damage of dNTP pools, is a promising target for designing effective anti-cancer drugs with low toxicities [1-4, 36-38].

As far as we know, farnesyl phenolic compounds are the first kind of natural products reported to exhibit MTH1 inhibitory activities. Therefore, this kind of compounds and their derivatives can be considered as lead compounds targeted MTH1 for drug development. Our work provides a reliable method to study the action mechanism of traditional Chinese medicine, and contributes to enrich structure scaffolds of MTH1 inhibitors. In our future study, the structural modifications and more detailed antitumor action mechanisms of farnesyl phenolic compounds will be further explored.

\section{MATERIALS AND METHODS}

\section{General experimental procedures}

Optical rotations were measured with a PerkinElmer 241 polarimeter (Perkin-Elmer, Waltham, MA, USA). UV spectra were recorded on a Shimadzu UV 2201 UV-VIS recording spectrophotometer (Shimadzu Corporation, Kyoto, Japan). ECD spectra were determined on a BioLogic Science MOS-450 spectrometer (Bio-Logic, Claix, France). IR (4000-400 $\mathrm{cm}^{-1}$ ) spectra ( $\mathrm{KBr}$ disks) were recorded on a Bruker IFS 55 spectrometer (BBruker Optics, Ettlingen, Germany). NMR experiments were performed on Bruker ARX-400 or AV-600 spectrometers (Bruker Biospin, Fallanden, Switzerland). Chemical shifts are stated relative to TMS and expressed in $\delta$ values (ppm), with coupling constants reported in Hz. HRESIMS were obtained on an Agilent 6210 TOF mass spectrometer (Palo Alto, USA). Silica gel GF254 prepared for TLC and silica gel (200-300 mesh) for column chromatography (CC) were obtained from Qingdao Marine Chemical Factory (Qingdao, China). Sephadex LH-20 was a product of Pharmacia (Amersharm, Sweden). Octadecyl silica gel was purchased from Merck Chemical Company Ltd (Darmstadt, Germany). RP-HPLC separations were conducted using a LC-6AD liquid chromatograph with a YMC Pack ODS-A column $(250 \times 20 \mathrm{~mm}, 5 \mu \mathrm{m}, 120$ $\AA$ ) and SPD-10AVP UV/vis detector (Shimadzu, Kyoto, Japan). Chiral-HPLC separations were conducted using a LC-6AD liquid chromatograph with a Daicel Chiralpak IE column $(250 \times 4.6 \mathrm{~mm}, 5 \mu \mathrm{m}$; Daicel, Japan $)$ and SPD10AVP UV/vis detector. All reagents were HPLC or analytical grade and were purchased from Tianjin Damao Chemical Company (Tianjin, China). Spots were detected on TLC plates under UV light or by heating after spraying with anisaldehyde- $\mathrm{H}_{2} \mathrm{SO}_{4}$ reagent.

\section{Plant material}

The fruiting bodies of Ganoderma sinense Zhao. $\mathrm{Xu}$ et Zhang were purchased from the Xunwu Prefecture 
of Jiangxi Province, People's Republic of China, and authenticated by Prof. Weining Wang at the Liaoning Institute for food and drug control. A voucher specimen (LZ-02-010) has been deposited in the same institution.

\section{Extraction and isolation}

The fruiting bodies of Ganoderma sinense Zhao. Xu et Zhang $(9.5 \mathrm{~kg})$ were cut into approximately $2 \mathrm{~cm}$ pieces and extracted with $95 \% \mathrm{EtOH}\left(100 \mathrm{~L} \times 2 \mathrm{~h} \times 2,40-50^{\circ} \mathrm{C}\right)$. The resulting extract $(233.6 \mathrm{~g})$ was concentrated in vacuo, suspended in $\mathrm{H}_{2} \mathrm{O}(5 \mathrm{~L})$, and partitioned successively with cyclohexane, EtOAc, and $n-\mathrm{BuOH}(5 \mathrm{~L} \times 3)$. After evaporation of EtOAc in vacuo, the residue $(81.4 \mathrm{~g})$ was subjected to silica gel CC $(10 \times 80 \mathrm{~cm} ; 200-300$ mesh, $500 \mathrm{~g})$ eluted with $\mathrm{CH}_{2} \mathrm{Cl}_{2} / \mathrm{MeOH}(100: 1,50: 1,20: 1,10: 1$, $5: 1,2: 1,1: 1$, and $0: 1 \mathrm{v} / \mathrm{v}$ ) to obtain eleven fractions (E1E11), which were combined according to TLC analysis. Fr. E5 $(26.3 \mathrm{~g})$ was chromatographed on a silica gel $\mathrm{CC}(6 \times 80 \mathrm{~cm} ; 200-300 \mathrm{mesh}, 300 \mathrm{~g})$ and eluted with a gradient of increasing acetone $(0-100 \%)$ in $\mathrm{CH}_{2} \mathrm{Cl}_{2}$, to produce five fractions (E51-E55). Separation of E53 (6.8 g) on a reversed-phase $\mathrm{C} 18$ silica gel $\mathrm{CC}(2.5 \times 30 \mathrm{~cm}$; 200-300 mesh, $100 \mathrm{~g})$ eluted with $\mathrm{MeOH} / \mathrm{H}_{2} \mathrm{O}(10: 90$, 30:70, 50:50, 70:30, and 100:0 v/v) yielded fractions E531 to E535. Fraction E532 $(500.2 \mathrm{mg})$ was separated further by Sephadex LH-20 CC $(2 \times 80 \mathrm{~cm})$ by elution with $\mathrm{MeOH}$ to give four subfractions (E5321-E5324). Fr. E533 (1.1 g) was subjected to Sephadex LH-20 $\mathrm{CC}(2 \times 80 \mathrm{~cm})$ by elution with $\mathrm{MeOH}$ to yield four subfractions (E5331-E5334). E5334 (307.9 mg) was purified by preparative HPLC $\left(65 \% \mathrm{MeOH} / \mathrm{H}_{2} \mathrm{O}\right.$, flow rate $6.0 \mathrm{~mL} / \mathrm{min})$ to afford $7 / 8\left(36.1 \mathrm{mg}, t_{\mathrm{R}} 70 \mathrm{~min}\right)$ and $1 / 2\left(110.5 \mathrm{mg}, t_{\mathrm{R}} 80 \mathrm{~min}\right)$. Fr. E534 (754.5 mg) was further chromatographed via Sephadex LH-20 CC $(2 \times 80 \mathrm{~cm})$ using $\mathrm{MeOH}$ to give five subfractions (E5341-E5345). Subfraction E5344 (334.9 mg) yielded $3 / 4\left(34.4 \mathrm{mg}, t_{\mathrm{R}}\right.$ $55 \mathrm{~min})$ and $5 / 6\left(20.4 \mathrm{mg}, t_{\mathrm{R}} 60 \mathrm{~min}\right)$ upon separation on a preparative HPLC $\left(45 \% \mathrm{MeCN} / \mathrm{H}_{2} \mathrm{O}\right.$, flow rate $6.0 \mathrm{~mL} /$ $\min )$.

Compounds $1 / 2,3 / 4,5 / 6$ and $7 / 8$ are enantiomeric mixtures, indicating by their optical rotations, ECD spectra and identical NMR data, which were subjected to chiral HPLC (Daicel Chiralpak IE, flow rate: $0.8 \mathrm{~mL} / \mathrm{min}$ ) to yield $(S)-2\left(5.8 \mathrm{mg}, t_{\mathrm{R}}=18.0 \mathrm{~min}\right)$ and $(R)-1\left(5.7 \mathrm{mg}, t_{\mathrm{R}}\right.$ $=22.0 \mathrm{~min})(n$-hexane/isopropanol, $75: 25),(R)-3(5.9 \mathrm{mg}$, $\left.t_{\mathrm{R}}=8.5 \mathrm{~min}\right)$ and $(S)-4\left(5.5 \mathrm{mg}, t_{\mathrm{R}}=13.0 \mathrm{~min}\right)(n$-hexane/ isopropanol, 65:35), $(S)-6\left(4.1 \mathrm{mg}, t_{\mathrm{R}}=16.5 \mathrm{~min}\right)$ and $(R)$ $5\left(4.4 \mathrm{mg}, t_{\mathrm{R}}=20.0 \mathrm{~min}\right)$ ( $n$-hexane/isopropanol, 75:25), $(S)-8\left(4.9 \mathrm{mg}, t_{\mathrm{R}}=20.5 \mathrm{~min}\right)$ and $(R)-7\left(5.0 \mathrm{mg}, t_{\mathrm{R}}=25.0\right.$ $\min$ ) ( $n$-hexane/isopropanol, 75:25).

\section{Spectroscopic data of the isolated compounds}

\section{Ganosinensols E (1) and F (2)}

pale yellow oil $(\mathrm{MeOH}) ;\left\{[\alpha]_{\mathrm{D}}^{20} 14(c 0.1, \mathrm{MeOH})\right.$; $\mathrm{CD}(\mathrm{MeOH}) \mathrm{nm}(\Delta \varepsilon) 210(-1.51), 230(+8.92) ;(R)-1\}$;
$\left\{[\alpha]_{\mathrm{D}}^{20}-47(c) 0.1, \mathrm{MeOH}\right) ; \mathrm{CD}(\mathrm{MeOH}) \mathrm{nm}(\Delta \varepsilon) 214$ (+2.41), 232 (-7.46); (S)-2\}; UV (MeOH) $\lambda_{\text {max }}(\log \varepsilon) 312$ (4.46) $\mathrm{nm}$; IR (KBr) $v_{\text {max }} 3383,2938,1755,1682,1605$, $1455,1170,1025,833 \mathrm{~cm}^{-1}$; ${ }^{1} \mathrm{H}$ NMR (400 MHz, CD $\mathrm{OD}$ ) and ${ }^{13} \mathrm{C}$ NMR (100 MHz, $\left.\mathrm{CD}_{3} \mathrm{OD}\right)$ data, see Table 2; HRESIMS (positive) $m / z 575.2260[\mathrm{M}+\mathrm{Na}]^{+}$(calcd for $\mathrm{C}_{31} \mathrm{H}_{36} \mathrm{O}_{9} \mathrm{Na}$, 575.2257).

\section{Ganosinensols $G(3)$ and $H(4)$}

pale yellow oil $(\mathrm{MeOH}) ;\left\{[\alpha]_{\mathrm{D}}^{20}-68(c 0.1, \mathrm{MeOH})\right.$; $\mathrm{CD}(\mathrm{MeOH}) \mathrm{nm}(\Delta \varepsilon) 208$ (-29.59), 250 (-2.50); $(R)-$ $3\} ;\left\{[\alpha]_{\mathrm{D}}^{20}+32(c 0.1, \mathrm{MeOH}) ; \mathrm{CD}(\mathrm{MeOH}) \mathrm{nm}(\Delta \varepsilon) 207\right.$ (+34.37), 249 (-0.92); (S)-4\}; UV (MeOH) $\lambda_{\max }(\log \varepsilon) 310$ (4.55) nm; IR (KBr) $v_{\text {max }} 3363,2940,1740,1691,1605$, $1453,1170,1023,833 \mathrm{~cm}^{-1}$; ${ }^{1} \mathrm{H}$ NMR (400 MHz, CD $\mathrm{OD}$ ) and ${ }^{13} \mathrm{C}$ NMR (100 MHz, $\left.\mathrm{CD}_{3} \mathrm{OD}\right)$ data, see Table 1 ; HRESIMS (positive) $\mathrm{m} / \mathrm{z} 545.2153[\mathrm{M}+\mathrm{Na}]^{+}$(calcd for $\left.\mathrm{C}_{30} \mathrm{H}_{34} \mathrm{O}_{8} \mathrm{Na}, 545.2151\right)$.

\section{Ganosinensols I (5) and J (6)}

pale yellow oil $(\mathrm{MeOH}) ;\left\{[\alpha]_{\mathrm{D}}^{20} 38(c 0.1, \mathrm{MeOH})\right.$; $\mathrm{CD}(\mathrm{MeOH}) \mathrm{nm}(\Delta \varepsilon) 210(-1.63), 231(+10.12) ;(R)-$ $5\} ;\left\{[\alpha]_{\mathrm{D}}^{20}-18\right.$ (c 0.1, MeOH); $\mathrm{CD}(\mathrm{MeOH}) \mathrm{nm}(\Delta \varepsilon) 211$ (+1.36), 231 (-7.30); (S)-6\}; UV (MeOH) $\lambda_{\text {max }}(\log \varepsilon) 313$ (4.37) nm; IR (KBr) $v_{\text {max }} 3427,2935,1747,1681,1605$, $1453,1168,1025,833 \mathrm{~cm}^{-1}$; ${ }^{1} \mathrm{H}$ NMR (400 MHz, DMSO$\left.d_{6}\right)$ and ${ }^{13} \mathrm{C}$ NMR (100 MHz, DMSO- $d_{6}$ ) data, see Table 2 ; HRESIMS (positive) $\mathrm{m} / \mathrm{z} 575.2261[\mathrm{M}+\mathrm{Na}]^{+}$(calcd for $\mathrm{C}_{31} \mathrm{H}_{36} \mathrm{O}_{9} \mathrm{Na}$, 575.2257).

\section{Structure based virtual ligand screening}

ICM 3.8.2 modeling software on an Intel i7 4960 processor (MolSoft LLC, San Diego, CA) was used to identify possible drug candidates for MTH1 enzyme. For the structure-based virtual screening, ligands were continuously resiliently made docking with MTH1 which was represented in potential energy maps. Compounds were scored according to the internal coordinate mechanics (Internal Coordinate Mechanics, ICM). Conformational sampling was based on the Monte Carlo procedure [39] and finally the lowest-energy and the most favorable orientation of the ligand were selected.

\section{Protein expression and purification of MTH1}

The gene of the human mutT homologue MTH1 was ligated into PET 28a vector (Novagen). After the recombinant plasmid was verified by sequencing, it was transformed into E. coli strain BL21 Star (Invitrogen) at $293 \mathrm{~K}$, which were grown in $\mathrm{LB}$ medium at $37^{\circ} \mathrm{C}$ to an OD600 (0.8-1.0) and induced by $0.4 \mathrm{mM}$ isopropylD-thiogalactopyranoside (IPTG) at $18^{\circ} \mathrm{C}$ for 16 hours. Bacterial cells were lysed by ultrasonification on ice in buffer containing $100 \mathrm{mM}$ Tris- $\mathrm{HCl} \mathrm{pH} 8.8,200$ $\mathrm{mM} \mathrm{NaCl}, 10 \%$ glycerol, $1 \%$ TritonX100, $5 \mathrm{mM}$ $\beta$-mercaptoethanol. Soluble N-terminally hexa-histidine 
tagged MTH1 was bound to Ni-agrose affinity resin (Qiagen), washed with a buffer containing $20 \mathrm{mM}$ Tris$\mathrm{HCl} \mathrm{pH} 8.8,200 \mathrm{mM} \mathrm{NaCl}$ and $10 \mathrm{mM}$ imidazole and eluted with a buffer containing $20 \mathrm{mM}$ Tris- $\mathrm{HCl} \mathrm{pH} 8.8$, $250 \mathrm{mM} \mathrm{NaCl}$, and $150 \mathrm{mM}$ imidazole. The eluted protein was concentrated and diluted with a buffer containing 20 $\mathrm{mM}$ Tris- $\mathrm{HCl} \mathrm{pH} 8.8,250 \mathrm{mM} \mathrm{NaCl}$ and digested with thrombin for $12-15 \mathrm{~h}$ at $277 \mathrm{~K}$. Cut MTH1 was purified by Ni-agrose affinity resin (Qiagen). The protein was further purified with anion exchange chromatography (GE Health), using a linear gradient of $10 \mathrm{mM}$ to $1 \mathrm{M} \mathrm{NaCl}$ concentration and size exclusion chromatography (GE Health) at $20 \mathrm{mM}$ Tris- $\mathrm{HCl} \mathrm{pH} 8.8$ and $200 \mathrm{mM} \mathrm{NaCl}$ [40].

\section{Microscale thermophoresis (MST) assay for in vitro binding affinity}

Recombinant human MTH1 was labeled with the Monolith NT ${ }^{\mathrm{TM}}$ Protein Labeling Kit RED (Cat\#L001) according to the supplied labeling protocol [32]. Labelled MTH1 was kept constant at $100 \mathrm{nM}$, while all samples tested were diluted in a $20 \mathrm{mM}$ HEPES ( $\mathrm{pH} 7.5)$ and 0.05 (v/v) \% Tween-20. Compounds were diluted in 12 dilution steps covering the range from $500 \mu \mathrm{M}$ to $200 \mathrm{nM}$. After 10 min incubation at room temperature about $37^{\circ} \mathrm{C}$, samples were loaded into Monolith ${ }^{\mathrm{TM}}$ standard-treated capillaries and the thermophoresis was measured at $25^{\circ} \mathrm{C}$ after $30 \mathrm{~min}$ incubation on a Monolith NT.115 instrument (NanoTemper Technologies, München, Germany). Laser power was set to $20 \%$ using 30 seconds on-time. The LED power was set to $100 \%$. The dissociation constant $\mathrm{Kd}$ values were fitted by using the NTAnalysis software (NanoTemper Technologies, München, Germany). The Kd value of the binding was obtained in two ways. The first way was calculated by thermophoresis curve when there was no fluorescent change during the initial fluorescence scanning. The second way was calculated from the initial fluorescence scanning curve when compounds bound in the sites which directly interfered the fluorescence. The appropriate way was employed to obtain $\mathrm{Kd}$ values of eight compounds and $(S)$-crizotinib.

\section{Enzyme inhibition assay}

To identify the efficacy of the eight compounds, an enzyme inhibition assay was carried out. A series of compounds in DMSO were incubated with purified MTH1 protein $(1.53 \mathrm{mg}$ protein $/ \mathrm{mL}, 6 \mu \mathrm{L})$ in $42 \mu \mathrm{L}$ buffer containing $5 \mathrm{mM} \mathrm{MgCl}_{2}$ and $100 \mathrm{mM}$ Tris- $\mathrm{HCl}$ $(\mathrm{pH} 8.5)$ at a temperature of $25^{\circ} \mathrm{C} .30 \mathrm{~min}$ later, 8-oxodGTP (final conc. $25 \mu \mathrm{M}, 6 \mu \mathrm{L}$ ) was added to the mixture, and reaction was processing at a temperature of $37^{\circ} \mathrm{C}$ and $200 \mathrm{rpm}$. Then the reaction was stop by the addition of $20 \mu \mathrm{L}$ ice-cold $\mathrm{Na}_{2}$ EDTA $(50 \mathrm{mM})$. The reaction mixture was centrifugated at $15000 \mathrm{rpm}$ at $4^{\circ} \mathrm{C}$ for $10 \mathrm{~min}$.
$20 \mu \mathrm{L}$ of supernatant was injected on an HPLC column (Ultimate AQ-C18 RP-18e, $250 \mathrm{~mm} \times 4.6 \mathrm{~mm} \times 5 \mu \mathrm{m}$ ), and eluted isolate with $100 \mathrm{mM} \mathrm{Na} \mathrm{HPO}_{4}-\mathrm{NaOH}(\mathrm{pH}$ $5.5) / \mathrm{MeOH}$ 95:5 with flow rate $1 \mathrm{~mL} / \mathrm{min}$ at column room of $30^{\circ} \mathrm{C}$. For detection of the formed 8-oxo-dGMP, the peak integrated with wavelength of $293 \mathrm{nM}$ [9]. The inhibition rates were calculated using the concentration ratios of 8-oxo-dGMP in tubes with or without various concentration compounds. Measurements were done in triplet, and $\mathrm{IC}_{50}$ values were calculated to compare the efficiency of various compounds.

\section{Cytotoxicity assay}

Carcinoma cell lines [human osteosarcoma cells (U2OS), human colorectal carcinoma cells (SW620), human ES-2 ovarian carcinoma cells (ES-2)] and normal tissue cell lines [human hepatic cells (Lo2), African green monkey kidney Vero cells (Vero)] The U2OS, SW620, ES2, Lo2 and Vero were obtained from ATCC (Manassas, VA, USA). The SW620 and Vero cells were cultured in Roswell Park Memorial Institute medium (RPMI), with $10 \%$ fetal bovine serum (Hyclone) and 1\% penicillinstreptomycin (Sigma). Lo2, U2OS and ES-2 cells were grown in Dulbecco's modified eagle medium (DMEM), with $10 \%$ fetal bovine serum (Hyclone) and 1\% penicillinstreptomycin (Sigma). All of these cells were cultured at $37^{\circ} \mathrm{C}$ in a humidified atmosphere with $5 \% \mathrm{CO}_{2}$. For CCK 8 assay cytotoxicity evaluation of compounds, all cells were separately plated at a density of $1 \times 10^{4}$ cells/well in a 96 well plate. Cells were cultivated at $37^{\circ} \mathrm{C}$ in $5 \%$ $\mathrm{CO}_{2}$ atmosphere for $24 \mathrm{~h}$, then medium in the wells was replaced with fresh medium containing compounds which were diluted in 8 dilution steps covering the range from $200 \mu \mathrm{M}$ to $1.5625 \mu \mathrm{M}$. And DMSO was used as negative control. After $48 \mathrm{~h}$ incubation, $10 \mu \mathrm{L}$ of CCK8 solution was added to each well. After $30 \mathrm{~min}$, the optical density (OD) of each well was measured at wavelength of $450 \mathrm{~nm}$ on spectrophotometer. Data were corrected for background (no-cell control) and expressed as a percentage of the value for untreated cells. The $\mathrm{IC}_{50}$ values of the isolated compounds were derived from the mean OD values of the triplicate tests versus the drug concentration curves [41].

\section{Apoptosis analysis}

Apoptotic cells were staining with Annexin-VFITC and Propidium Iodide (PI) (Annexin V-FITC/PI double staining cell apoptosis detection kit) following the manufacturer's protocol. Fluorescence was recorded by flow cytometry using the FACSort (BD Bio sciences) [42].

\section{EdU cell proliferation assay}

SW620 cells were pretreated with $0,50,150 \mu \mathrm{M}$ of compound 1, respectively. Dissociated cells were handled with EdU cell proliferation kit (RiboBio) according 
to the manuscript by according to the manufacturer's instructions. Then the morphology was observed by fluorescence microscopy (Zeiss, OBSERVER D1/AX10 cam HRC) [43].

\section{Immunofluorescence}

Cells which adhered to glass coverslips were treated with DMSO or compounds $(50 \mu \mathrm{M})$ for $24 \mathrm{~h}$. Then cells were washed with PBS and then fixed with $3 \%$ paraformaldehyde in PBS for $20 \mathrm{~min}$ at $-20^{\circ} \mathrm{C}$. Fixed cells were rinsed with PBS and incubated with penetrating agent $(0.5 \%$ Triton-X-100) in PBS for 5 min. Next, cells were stained with an anti-53BP1 monoclonal antibody (abcam, diluted 1:250). Then the coverslips were rinsed with PBS at least 3 times andincubated with an Alexa Fluor 568 goat anti-rabbit IgG secondary antibody. After PBS rinsing, coverslips were stained with DAPI (sigma). Then the morphology was observed by confocal microscopy (Zeiss, OBSERVER D1/AX10 cam HRC) [8].

\section{Transfections and $\mathrm{IC}_{50}$ value determination}

SW620 cells were seeded with $5 \times 10^{5}$ cells/well in 6 well plates and were transfected at $60-70 \%$ confluence the next day using $200 \mathrm{nM}$ MTH1 siRNA or NT siRNA (GenePharma) complexed with $2 \mu \mathrm{g} / \mathrm{ml}$ Lipofectamine ${ }^{\mathrm{TM}}$ 2000 (Invitrogen, Cat. No. 11668-030) following the protocol of manufacture. Cells were cultured in optiMEM media (Gibco) during transfection. The three siRNA sequences were showed as below.

MTH1 siRNA\#1 GACGACAG CUACUGGUUUC; MTH1 siRNA\#2 GAAAUUCCACGGGUACUUC; MTH1 siRNA \#3 CGACGACAGCUACUGGUUU.

After transfection for 6 hours, opti-MEM media were replaced with DMEM media. And 48 hours later, cells were washed with PBS and suspended with PBS containing $1 \mathrm{mM}$ PMSF, and followed by Western blot assay. The $\mathrm{IC}_{50}$ of compound 1 was retested using siRNA transfected cells $[2,44]$.

\section{Cellular thermal shift assay (CETSA)}

CETSA was developed as a method to directly detect the binding capacity of compounds with targets at the cellular level, based on the principle of ligand-induced target protein stabilization. Briefly, SW620 cells cultured with $90 \%$ confluent in $100 \times 20 \mathrm{~mm}$ tissue culture dishes were treated with media containing DMSO or compound $1(30 \mu \mathrm{M})$ for 12 hours. After treatment, the cells were isolated with trypsin, collected by centrifugation, and then resuspended in PBS. The cell suspension was divided equally into 4 PCR tubes and heated to $44,46,48,50,52$, and $54^{\circ} \mathrm{C}$ for 3 minutes, respectively. Subsequently, cells were analysed by Western blot assay [45-46].

\section{Western blot assay}

The harvested cells were lysed with liquid nitrogen and the freeze-thaw cycles were repeated twice. The soluble proteins were separated from the cell pellet by centrifugation at $14,000 \mathrm{~g}$ for $20 \mathrm{~min}$. Proteins was quantified by Bradford reagent (Bio-Rad, USA). The same amount of proteins $(20-40 \mu \mathrm{g})$ were loaded onto $15 \%$ SDS-PAGE gels and transferred to polyvinylidene difluoride membranes (PVDF) (Millipore, USA) and analyzed using the MTH1-antibody (Proteintech) at a concentration of 1: 500. The level of protein expression in Western blot was quantified by optical density analysis using Image J software program (NIH) [42].

\section{Abbreviations}

MTH1: human mutT homologue; CETSA: cellular thermal shift assay; ROS: reactive oxygen species; OD: the optical density; IPTG: isopropylß-D-1thiogalactopyranoside; MST: microscale thermophoresis; PMSF: phenylmethanesulfonyluoride; PVDF: Polyvinylidene difluoride.

\section{Author contributions}

L.-X. C. and H. L. initiated the project. L.-X. C. and H. L. designed and coordinated the project. L.-H. Z., T. Y., and L.-Q. W. performed the extraction, isolation, and structural identification of the compounds. Y. G. and J. G. carried out structure based virtual ligand screening, protein expression and purification of MTH1, microscale thermophoresis (MST) Assay, enzyme inhibition assay, cytotoxicity Assay, transfections and $\mathrm{IC}_{50}$ value determination, cellular thermal shift assay (CETSA) and western blot assay. L.-X. C, H. L, and Y. G. analyzed the data of the biological assay. The manuscript was prepared by Y. G.. All authors approved the final version of the manuscript.

\section{ACKNOWLEDGMENTS}

Financial support from the Project of Innovation Team (LT2015027) of Liaoning of P.R. China, Key Projects of the National Science and Technology Pillar Program (Grant No. 2012BAI30B02), and Wen Li and Yi Sha of Shenyang Pharmaceutical University for recording the NMR spectra, are gratefully acknowledged.

\section{CONFLICTS OF INTEREST}

The authors declare no competing financial interests.

\section{FUNDING}

None. 


\section{REFERENCES}

1. Fouquerel E, Lormand J, Bose A, Lee HT, Kim GS, Li J, Sobol RW, Freudenthal BD, Myong S, Opresko PL. Oxidative guanine base damage regulates human telomerase activity. Nat Sturct Mol Biol. 2016; 23:1092-1100. https:// doi.org/10.1038/nsmb.3319.

2. Gad H, Koolmeister T, Jemth AS, Eshtad S, Jacques SA, Ström CE, Svensson LM, Schultz N, Lundbäck T, Einarsdottir BO, Saleh A, Göktürk C, Baranczewski P, et al. MTH1 inhibition eradicates cancer by preventing sanitation of dNTP pool. Nature. 2014; 508:215-221. https://doi. org/10.1038/nature13181.

3. Burton DG, Rai P. MTH1 counteracts oncogenic oxidative stress. Oncoscience. 2015; 2:785-786. https://doi. org/10.18632/oncoscience.240.

4. Fujikawa K, Kamiya H, Yakushiji H, Fujii Y, Nakabeppu $\mathrm{Y}$, Kasai $\mathrm{H}$. The oxidized forms of dATP are substrates for the human MutT homologue, the hMTH1 protein. J Biol Chem. 1999; 274:18201-18205. https://doi.org/10.1074/ jbc.274.26.18201.

5. Oka S, Ohno M, Tsuchimoto D, Sakumi K, Furuichi M, Nakabeppu Y. Two distinct pathways of cell death triggered by oxidative damage to nuclear and mitochondrial DNAs. EMBO J. 2008; 27:421-432. https://doi.org/10.1038/ sj.emboj.7601975.

6. Yoshimura D, Sakumi K, Ohno M, Sakai Y, Furuichi M, Iwai S, Nakabeppu Y. An oxidized purine nucleoside triphosphatase, MTH1, suppresses cell death caused by oxidative stress. J Biol Chem. 2003; 278:37965-37973. https://doi.org/10.1074/jbc.M306201200.

7. Li L, Song L, Liu X, Yang X, Li X, He T, Wang N, Yang S, Yu C, Yin T, Wen Y, He Z, Wei X, et al. Artificial virus delivers CRISPR-Cas9 system for genome editing of cells in mice. ACS Nano. 2017; 11:95-111. https://doi. org/10.1021/acsnano.6b04261.

8. Huber KV, Salah E, Radic B, Gridling M, Elkins JM, Stukalov A, Jemth AS, Göktürk C, Sanjiv K, Strömberg K, Pham T, Berglund UW, Colinge J, et al. Stereospecific targeting of MTH1 by (S)-crizotinib as an anticancer strategy. Nature. 2014; 508:222-227. https://doi. org/10.1038/nature13194.

9. Streib M, Kräling K, Richter K, Xie X, Steuber H, Meggers E. An organometallic inhibitor for the human repair enzyme 7,8-dihydro-8-oxoguanosine triphosphatase. Angew Chem Int Ed Engl. 2014; 53:305-309. https://doi.org/10.1002/ anie.201307849.

10. Yin Y, Sasaki S, Taniguchi Y. Inhibitory effect of 8-halogenated 7-deaza-2'- deoxyguanosine triphosphates on human 8-oxo-2'-deoxyguanosine triphosphatase, hMTH1, activities. Chembiochem. 2016; 17:566-569. https://doi. org/10.1002/cbic.201500589.

11. Newman DJ, Cragg GM. Natural products as sources of new drugs from 1981 to 2014. J Nat Prod. 2014; 79:629661. https://doi.org/10.1021/acs.jnatprod.5b01055.
12. Abagyan R, Totrov M, Kuznetsov D. ICM-A new method for protein modeling and design: Applications to docking and structure prediction from the distorted native conformation. J Comput Chem. 1994; 15:488-506. https:// doi.org/10.1002/jcc.540150503.

13. State Pharmacopoeia Commission of People's Republic of China. Pharmacopoeia of the People's Republic of China, Part 1:188-189 (Chinese Medical Science and Technology, 2015).

14. Liang Z, Yi Y, Guo Y, Wang R, Hu Q, Xiong X. Chemical characterization and antitumor activities of polysaccharide extracted from Ganoderma lucidum. Int J Mol Sci. 2014; 15:9103-9116. https://doi.org/10.3390/ijms15059103.

15. Sun X, Zhao C, Pan W, Wang J, Wang W. Carboxylate groups play a major role in antitumor activity of Ganoderma applanatum polysaccharide. Carbohydr Polym. 2015; 123:283-287. https://doi.org/10.1016/j.carbpol.2015.01.062.

16. Yu Q, Nie SP, Wang JQ, Huang DF, Li WJ, Xie MY. Tolllike receptor 4 mediates the antitumor host response induced by Ganoderma atrum polysaccharide. J Agric Food Chem. 2015; 63:517-525. https://doi.org/10.1021/jf5041096.

17. Ko HH, Hung CF, Wang JP, Lin CN. Antiinflammatory triterpenoids and steroids from Ganoderma lucidum and G. tsugae. Phytochemistry. 2008; 69:234-239. https://doi. org/10.1016/j.phytochem.2007.06.008.

18. Joseph S, Sabulal B, George V, Smina TP, Janardhanan KK. Antioxidative and antiinflammatory activities of the chloroform extract of Ganoderma lucidum found in south india. Sci Pharm. 2009; 77:111-121. https://doi.org/10.3797/ scipharm.0808-17.

19. Shi Y, Cai D, Wang X, Liu X. Immunomodulatory effect of Ganoderma lucidum polysaccharides (GLP) on long-term heavy-load exercising mice. Int J Vitam Nutr Res. 2012; 82:383-390. https://doi.org/10.1024/0300-9831/a000135.

20. Jan RH, Lin TY, Hsu YC, Lee SS, Lo SY, Chang M, Chen LK, Lin YL. Immuno-modulatory activity of Ganoderma lucidum-derived polysacharide on human monocytoid dendritic cells pulsed with Der p 1 allergen. BMC Immunol. 2011; 12:31. https://doi.org/10.1186/1471-2172-12-31.

21. Liu YJ, Du JL, Cao LP, Jia R, Shen YJ, Zhao CY, Xu P, Yin GJ. Anti-inflammatory and hepatoprotective effects of Ganoderma lucidum polysaccharides on carbon tetrachloride-induced hepatocyte damage in common carp (Cyprinus carpio L.). Int Immunopharmacol. 2015; 25:112120. https://doi.org/10.1016/j.intimp.2015.01.023.

22. Kikuchi T, Matsuda S, Kadota S, Murai Y, Ogita Z. Ganoderic acid D, E, F, and $\mathrm{H}$ and lucidenic acid D, E, and $\mathrm{F}$, new triterpenoids from Ganoderma lucidum. Chem Pharm Bull. 1985; 33:2624-2627.

23. Ríos JL, Andújar I, Recio MC, Giner RM. Lanostanoids from fungi: a group of potential anticancer compounds. J Nat Prod. 2016; 75:2016-2044. https://doi.org/10.1021/ np300412h.

24. Isaka $\mathrm{M}$, Chinthanom $\mathrm{P}$, Kongthong $\mathrm{S}$, Srichomthong K, Choeyklin R. Lanostane triterpenes from cultures 
of the basidiomycete Ganoderma orbiforme BCC 22324. Phytochemistry. 2013; 87:133-139. https://doi. org/10.1016/j.phytochem.2012.11.022.

25. Peng XR, Liu JQ, Wang CF, Li XY, Shu Y, Zhou L, Qiu $\mathrm{MH}$. Hepatoprotective effects of triterpenoids from Ganoderma cochlear. J Nat Prod. 2014; 77:734-743. https:// doi.org/10.1021/np400323u.

26. Paterson RR. Ganoderma - a therapeutic fungal biofactory. Phytochemistry. 2016; 67:1985-2001. https://doi. org/10.1016/j.phytochem.2006.07.004.

27. Mothana RA, Jansen R, Jülich WD, Lindequist U. Ganomycins A and B, new antimicrobial farnesyl hydroquinones from the basidiomycete Ganoderma pfeifferi. J Nat Prod. 2000; 63:416-418. https://doi. org/10.1021/np990381y.

28. Niu XM, Li SH, Sun HD, Che CT. Prenylated phenolics from Ganoderma fornicatum. J Nat Prod. 2006; 69:13641365. https://doi.org/10.1021/np060218k.

29. El Dine RS, El Halawany AM, Ma CM, Hattori M. Inhibition of the dimerization and active site of HIV-1 protease by secondary metabolites from the Vietnamese mushroom Ganoderma colossum. J Nat Prod. 2009; 72:2019-2023. https://doi.org/10.1021/np900279u.

30. Timo HJ, Niedermeyer, Thomas J, Michael L, Ulrike L. Isolation of farnesylhydroquinones from the basidiomycete Ganoderma pfeifferi. Nat Prod Bioprospect. 2013; 3:137140. https://doi.org/10.1007/s13659-013-0036-5.

31. Wang M, Wang F, Xu F, Ding LQ, Zhang Q, Li HX, Zhao F, Wang LQ, Zhu LH, Chen LZ, Qiu F. Two pairs of farnesyl phenolic enantiomers as natural nitric oxide inhibitors from Ganoderma sinese. Bioorg. Med Chem Lett. 2016; 26:33423345. https://doi.org/10.1016/j.bmcl.2016.05.037.

32. Parker JL, Simon N. Molecular basis of nitrate uptake by the plant nitrate transporter NRT1.1. Nature. 2014; 507:6872. https://doi.org/10.1038/nature13116.

33. Kettle JG, Alwan H, Bista M, Breed J, Davies NL, Eckersley K, Fillery S, Foote KM, Goodwin L, Jones DR, Käck H, Lau A, Nissink JW, et al. Potent and selective inhibitors of MTH1 probe its role in cancer cell survival. J Med Chem. 2016; 59:2346-2361. https://doi.org/10.1021/ acs.jmedchem.5b01760.

34. Petrocchi A, Leo E, Reyna NJ, Hamilton MM, Shi X, Parker CA, Mseeh F, Bardenhagen JP, Leonard P, Cross JB, Huang S, Jiang Y, Cardozo M, et al. Identification of potent and selective MTH1 inhibitors. Bioorg Med Chem Lett. 2016; 26:1503-1507. https://doi.org/10.1016/j.bmcl.2016.02.026.

35. Kawamura T, Kawatani M, Muroi M, Kondoh Y, Futamura Y, Aono H, Tanaka M, Honda K, Osada H. Proteomic profiling of small molecule inhibitors reveals dispensability of MTH1 for cancer cell survival. Sci Rep. 2016; 6:26521. https://doi.org/10.1038/srep26521.

36. Wang M, Zhou SL, Chen Q, Wang LS, Liang ZQ, Wang JY. Understanding the molecular mechanism for the differntial inhibitory activities of compounds against MTH. Sci Rep. 2016; 7:40557. https://doi.org/10.1038/srep40557.

37. Cramer SL, Saha A, Liu JY, Tadi S, Tiziani S, Yan WP, Triplett K, Lamb C, Alters SE, Rowlinson S, Zhang YS, Keating KJ, Huang P, et al. Systemic depletion of L-cyst(e) ine with cyst(e)inase increases reactive oxygen species and suppresses tumor growth. Nat Med. 2017; 23:120-127. https://doi.org/10.1038/nm.4232.

38. Doskey CM, Buranasudja V, Wagner BA, Wilkes JG, Du J, Cullen JJ, Buettner GR. Tumor cells have decreased ability to metabolize H2O2: Implications for pharmacological ascorbate in cancer therapy. Redox Bio. 2016; 10:274-284. https://doi.org/10.1016/j.redox.2016.10.010.

39. Li Z, Scheraga HA. Monte Carlo-minimization approach to the multiple-minima problem in protein folding. Proc Natl Acad Sci U S A. 1987; 84:6111-6115.

40. Sun W, Chen X, Tong Q, Zhu H, He Y, Lei L, Xue Y, Yao G, Luo Z, Wang J, Li H, Zhang Y. Novel small molecule $11 \beta$ HSD1 inhibitor from the endophytic fungus Penicillium commune. Sci Rep. 2016; 6:26418. https://doi.org/10.1038/ srep26418.

41. Mohindra A, Hays LE, Phillips EN, Preston BD, Helleday T, Meuth M. Defects in homologous recombination repair in mismatch-repair-deficient tumour cell lines. Hum Mol Genet. 2002; 11:2189-2200. https://doi.org/10.1093/ $\mathrm{hmg} / 11.18 .2189$.

42. Zheng M, Sun W, Gao S, Luan S, Li D, Chen R, Zhang Q, Chen L, Huang J, Li H. Structure based discovery of clomifene as a potent inhibitor of cancer-associated mutant IDH1. Oncotarget. 2017; 8:44255-44265. https://doi. org/10.18632/oncotarget.17464.

43. Ding D, Zhang Y, Wen L, Fu J, Bai X, Fan Y, Lin Y, Dai H, Li Q, Zhang Y, An R. MiR-367 regulates cell proliferation and metastasis by targeting metastasis-associated protein 3 (MTA3) in clear-cell renal cell carcinoma. Oncotarget. 2017; 8:63084-63095. https://doi.org/10.18632/ oncotarget.18647.

44. Kim DJ, Li Y, Reddy K, Lee MH, Kim MO, Cho YY, Lee SY, Kim JE, Bode AM, Dong Z. Novel TOPK inhibitor HI-TOPK-032 effectively suppresses colon cancer growth. Cancer Res. 2012; 72:3060. https://doi. org/10.1158/0008-5472.

45. Martinez Molina D, Jafari R, Ignatushchenko M, Seki T, Larsson EA, Dan C, Sreekumar L, Cao Y, Nordlund P. Monitoring drug target engagement in cells and tissues using the cellular thermal shift assay. Science. 2013; 341:84-87. https://doi.org/10.1126/science.1233606.

46. Alshareef A, Zhang HF, Huang YH, Wu C, Zhang JD, Wang P, El-Sehemy A, Fares M, Lai R. The use of cellular thermal shift assay (CETSA) to study Crizotinib resistance in ALKexpressing human cancers. Sci Rep. 2016; 6:33710. https:// doi.org/10.1038/srep33710. 